\title{
Sosyoekonomik Katmanlarda Dil Kullanımı
}

Fatih Doğru' - Ferdi BOZKURT²

\section{Öz}

Bu çalışmada sosyoekonomik katmanlara göre dil kullanım farklılıklarını ortaya koymak amaçlanmıştır. Tüketiciden tüketiciye e-ticaret olanağı sağlayan ve ilan metnini satıcının özgün biçimde oluşturabildiği bir platform olan sahibinden.com internet sitesindeki farklı fiyat aralıklarında yer alan otomobil ilan açıklamalarındaki dil kullanım özellikleri incelenmiştir. Bu çalışma kapsamında 7063 sözcükten oluşan bir derlem oluşturulmuştur. Derlemde; söz dizimi başlığı altında tümce sayısı, tümce uzunluğu, tümce yapısı, tümce biçimi, edilgen çatılı tümceler, yüklemin türüne göre tümceler, yüklemin yerine göre tümceler, eylemsiler (ortaçlar, ulaçlar, ad-eylemler); söz varlığı başlığı altında sözcük sayısı, sözcük çeşitliliği, önadlar, belirteçler, ilgeçler, bağlaçlar, adıllar, ünlemler, kısaltmalar, yabancı söz kullanımı; edimbilgisel özellikler başlı̆̆ı altında nezaket gösteren biçimbirimler, emirler, sorular; diğer dil kullanım özellikleri başlığı altında ise yazım yanlışları, noktalama yanlışları, büyükküçük harf kullanım tercihleri işaretlenmiştir. Bu özelliklerin sosyoekonomik katman, toplumsal sınıf ve dilsel kodlara göre sayıları, dağılımları ve oranları tespit edilmeye çalışılmıştır. Çalışmada sosyoekonomik katmanlar en alt katman, alt katman, orta alt katman, orta katman, üst katman ve en üst katman; toplumsal sınıflar alt sınıf, orta sınıf ve üst sınıf; dilsel kodlar ise dar kod ve geniş kod olmak üzere gruplandırılmıştır. Bu gruplar arasında dil kullanımı bakımından benzerlik ve farklılık gösteren yönler irdelenmiştir. Çalışma sonucunda farklı sosyoekonomik katmanlardaki bireylerin dil kullanımlarıla ilgili birtakım farklılıklar görüldüğü tespit edilmiştir. Toplumdilbilime ilişkin temel alanyazında ön plana çıkan araştırmalardaki bulguların büyük bir bölümünün bu çalışma ile parallellik gösterdiği sonucuna ulaşılmıştır.

Anahtar Kelimeler: Toplumdilbilim, Sosyoekonomik Katmanlar, Toplumsal Sınıflar, Dilsel Kodlar, Dil Kullanımı.

\footnotetext{
${ }^{1}$ Arş. Gör. Dr., Eskişehir Osmangazi Üniversitesi, Fen-Edebiyat Fakültesi, Türk Dili ve Edebiyatı Bölümü, fdogru@ogu.edu.tr, ORCID: 0000-0002-1801-9725.

${ }^{2}$ Dr. Öğr. Üyesi, Anadolu Üniversitesi, Açıköğretim Fakültesi, Türk Dili ve Edebiyatı Bölümü, ferdib@anadolu.edu.tr, ORCID: 0000-0002-2209-8673.
} 


\title{
Language Use on Socio-Economic Strata
}

\begin{abstract}
In this study, it is aimed to reveal language usage differences according to socioeconomic strata. sahibinden.com is a platform where the seller can write the ad description texts originally. The language usage features in automobile ad descriptions in different value ranges on the sahibinden.com website which provides e-commerce to the customer to customer ( $\left.\mathrm{C}_{2} \mathrm{C}\right)$ were examined. In this study, a corpus of 7063 running words was built. The numbers of sentences, length of sentences, structures of sentences (gramatically simple/complex, syntactically nominal/verbal, syntactically inverted/regular), types of sentences, passive voice verbs, participles, gerunds, infinitives were tagged under the title of syntax in the corpus. The numbers of words, lexical diversity, adjectives, adverbs, prepositions, conjunctions, pronouns, interjections, abbreviations, use of foreign words were tagged under the title of vocabulary in the corpus. Imperatives, questions and suffixes for politeness were tagged under the title of pragmatic features in the corpus. Misspellings, punctuation mistakes and capitalization preferences were tagged under the title of other language usage features in the corpus. The numbers, dispersions and ratios of these features were determined according to socio-economic strata, social classes and linguistic codes. Socioeconomic strata were grouped as the lowest stratum, the lower stratum, the middle-lower stratum, the middle stratum, the upper stratum and the highest stratum. Social classes were grouped as the lower class, the middle class and the upper class. Linguistic codes were grouped as the restricted code and the elaborated code in the study. Similarities and differences in language use were examined between these groups. Some differences in the language use of individuals from different socioeconomic strata was determined as a result of the study. The most of the findings of the current study are parallel to the prominent researches of the sociolinguistic field.
\end{abstract}

Keywords: Sociolinguistics, Socio-Economic Strata, Social Class, Linguistic Codes, Language Use.

\section{Extended Abstract}

This study focuses on different language usage characteristics according to socioeconomic strata, social classes, and linguistic codes. We utilized the texts in automobile ad descriptions on the sahibinden.com website which provides e-commerce from customer to customer $(C 2 C)$ to reveal these linguistic similarities and differences. We created the socioeconomic strata based on automobile values. This study aims to determine whether there is a relevance between the language usage of native speakers from different socioeconomic strata, and to explain in which language usage characteristics this relevance occurs. In addition, we aimed to answer the following research questions in the study. Is there any relevance between the socioeconomic stratum and language usage in Turkish? How does language usage change at different socioeconomic strata? What are the 
parameters in Turkish usage in texts created by people of high or low income? The socioeconomic strata are divided into six groups as the lowest, the lower, lower-middle, middle, upper, and the highest. Social classes are divided into three groups as lower, middle, and upper. Linguistic codes are divided into two groups as restricted and elaborated. We found some differences between the codes in terms of the numbers of words and sentences. The numbers of words and sentences in restricted code are less than elaborated code.

\section{Syntax}

Sentences in restricted code are significantly shorter than elaborated code. The rate of simple sentences in restricted code is higher than in elaborated code. Stereotypes are used more frequently in the restricted code than in the elaborated code. Active verbs are used more in restricted code than in elaborated code. The passive verbs are used more in the elaborated code than the restricted code. Inverted sentences are used more in restricted code than in elaborated code according to the total ratio of the number of sentences. Nominal sentences are less in restricted code than in elaborated code. On the other hand, verbal sentences are less in elaborated code than in restricted code. There is no significant difference between the codes in the use of participles. Gerunds and infinitives are used more frequently in elaborated code than in restricted code. Findings about syntax features generally support Bernstein's (1959) statements.

\section{Vocabulary}

No meaningful results could be obtained in lexical diversity between linguistic codes. Although these results seem to contradictory Bernstein's (1959) statements, different results can be obtained in another study that is going to be conducted on a balanced corpus. An entirely similar situation exists for the other vocabulary features. For instance, there is no significant difference in the usage of adjectives and adverbs between the codes. The lexical findings of the study don't present an expressive difference between restricted and elaborated codes in terms of the number of preposition usage. However, the variety of prepositions is greater in elaborated code than restricted code. Conjunctions are less in restricted code than in elaborated code. There is no significant difference between restricted and elaborated codes in terms of pronoun usage, but it was determined that there are some differences according to the types of pronouns. Especially indefinite pronouns are used much more in elaborated code than in restricted code. There are noticeable differences between restricted code and elaborated code regarding the use of interjections. There is no significant difference between restricted and elaborated codes in terms of the abbreviation usage, but nonstandard abbreviations are used much more in restricted code than in elaborated code. The most obvious difference between the codes is the usage rate of foreign words.

\section{Pragmatic Features}

There are significant differences between restricted code and elaborated code regarding the use of imperatives. The usage rate of questions is less in elaborated code than in restricted code. It can be said that the 
preference of longer morphemes in restricted code as compared to the elaborated code increases the politeness degree in elaborated code.

Other Language Usage Features

It has been determined that there are fewer spelling mistakes in elaborated code than in restricted code. A similar result was observed in rates of punctuation mistakes. Preference of all letters capitalized words is used more in elaborated code than in restricted code.

As a result of these findings, it can be said that the most remarkable differences between restricted and elaborated codes are capitalization preferences and the use of foreign words. In summary, it is possible to say that the text production of native speakers in elaborated code is closer to formal language. 


\section{Giriş}

Dünya nüfusu 2021 yılı itibariyle 7,8 milyar insandan oluşmaktadır (Worldometers, 2021). Tam sayısı tartışmalı olmakla birlikte dünya üzerinde yaklaşık 6 bin dil vardır. Dünyadaki dil sayısı ve insan sayısı kıyaslandığında bazı dillerin yüz binlerce, bazı dillerin milyonlarca konuşuru olduğu gerçeği ortaya çıkmaktadır. Ancak aynı dili konuşan insanların bu dilleri ne derece aynı konuştukları merak konusu olmuştur. Yani dilin, konuşulduğu bölgelere göre ne kadar ve nasıl farklılaştığı, toplumdaki farklı insan topluluklarındaki değişik dil kullanımları ya da aynı dili konuşan bireylerin eğitim düzeyleri ile dil kullanımları arasında ne gibi bir ilişki olduğu soruları dil araştırmacılarının dikkatini çekmiştir.

Özellikle 1900'lerin başından itibaren çeşitli bilim dalları birlikte hareket etmeye başlamış; kendi aralarında teknik, yöntem, yaklaşım, kuram paylaşımlarına başlamıştır. Bu birlikteliklerden biri de toplumbilim ve dilbilim arasında gerçekleșmiş, ortaya toplumdilbilim çıkmıştır.

Toplumdilbilim terimi, ilk kez 1939 yılında Thomas Callan Hodson'ın “Man in India" adlı kitabının içinde yayımlanmış "Sociolingusitics in India" adlı makalesinde kullanılmıștır (Paulston ve Tucker, 2003). Bussmann (2006: 1089) toplumdilbilim (sociolinguistics) terimini "Dil sisteminin ve dil kullanımının toplumsal anlamını ve dilsel ve toplumsal yapının ortak koşullarını araştıran dilbilim ve sosyolojinin iş birliği sonucu ortaya çıkmış bir bilimsel disiplin." biçiminde tanımlayarak toplumdilbilimde hedeflenen çalışma alanına işaret etmektedir. İmer vd. (2013: 247) ise toplumdilbilimi "Dil ve toplum arasındaki ilişkilerin tüm görünümleriyle ve çeşitli kuram, yaklaşım ve modellere dayanılarak araştırıldığı dal” biçiminde tanımlamaktadırlar.

\subsection{Toplumsal Katmanlar ve Dil Kullanımı}

Toplumu oluşturan bireylerin bir ya da birden fazla ölçüte göre ayrıldığında ortaya çıkan gruplar, toplumsal katmanları oluşturmaktadır. Toplumbilim alanyazınında toplumsal sınıf ve katmanlara dair çeşitli sınıflandırmalar ${ }^{3}$ mevcuttur.Kalaycıoğlu'na (2002: 303) göre günümüzde sanayileşmiş, ekonomik olarak gelişmiş toplumlarda üç temel toplumsal sınıf olduğu varsayılmaktadır:

“Üst sınıf: işveren, sanayici, gayrimenkul ve menkul sahipliği, üst düzey yönetici konumunda toplumsal kaynaklara sahip veya kontrol edebilen grup.

\footnotetext{
3 Sınıf kavramı toplumbilimin uzunca bir süredir çalıșma alanını oluşturan geniş bir kavramdır. Sınıf kavramına sosyalizm, kapitalizm gibi ekonomik sistemler farklı yaklaşmaktadır. Bu makalede bu tartışma konularına girilmeyecektir. Çalışmada toplumsal sınıflar/katmanlar ele alınırken gelişmiş ülkelerde son yıllarda ortak kabul görmüş bir sınıflandırma tercih edilmiştir. Sınıf ve katman kavramına ilişkin daha kapsamlı bilgi için bakınız Giddens (2012, 336-381).
} 
Orta sınıf: beyaz yakalı, masa başı iş yapan konumunda çalışanlar, profesyonel mesleklere sahip olanlar, devlet görevlileri.

Alt sınıf: mavi yakalı, genellikle imalatta çalışan işçiler, el emeği ile çalışanlar, devlet görevinde daha alt ücretli işlerde çalışanlar."

Bu sınıflandırmada görüleceği üzere toplumsal sınıfları oluşturan ana etkenlerin başında meslekler ve gelir düzeyleri gelmektedir.

Toplumbilimin, toplumsal katmanların ve sınıfların arasındaki dil kullanımı farklılıklarını ve benzerliklerini ortaya koyma arayışı kendini dilbilim alanında da göstermiş ve süreç içerisinde toplumdilimin çalışma alanları ortaya çıkmıştır. Toplumdilbilim ile ilgili dönüm noktası olan sistematik araştırmalar 1960’larda Ingiltere'de Basil Bernstein ile, Amerika'da ise William Labov ile başlamıştır. Bernstein'ın 1960'lı yıllarda ortaya attığı “Eksiklik Kuramı” toplumdilbilimin gelişmesinde bir dönüm noktası olmuştur. Bernstein; toplumsal gruplara özgü dil kullanımının değişken olduğunu, farklı katmanlardan bireylerin dil kullanımlarının değişebildiğini ve aradaki bu farklılığın bir "eksiklik" oluşturduğunu ifade etmiştir (İmer, 1990: 21).

Bernstein'ın 1958 yılında yayımladığı Algının Bazı Toplumbilimsel Belirleyicileri (Some Sociological Determinants of Perception) adlı makalesindeki bilgilerden yola çıkarak hazırladığı Bir Kamusal Dil: Dilbilimsel Bir Biçimin Bazı Toplumbilimsel Çıkarımları (A Public Language : Some Sociological Implications of a Linguistic Form) adlı çalışmasında kamu (halk) dilinin bazı karakteristik özelliklerini ortaya koymuştur (Bernstein, 1959: 311). Bernstein, public language "halk dili, kamu dili, kamusal dil" yerine sonraki çalışmalarında restricted code "dar kod"; formal language "kurallı dil" yerine ise elaborated language "geniş kod” terimlerini kullanmıştır (İmer, 1990: 24-26).

Temellerini ortaya koyduğu “Eksiklik Kuramı”yla Bernstein; dilleri ve lehçeleri farklıık (difference) bakış açısıyla ele almak yerine eksiklik (deficit) bakış açısıyla ele aldığı için toplumdilbilimcilerin ağır eleştirilerine maruz kalmıştır (Swann, 2004: 26). Bernstein'ı eleştiren toplumdilbilimcilerden biri de Labov'dur. Labov, eleştirilerden yola çıkarak “Ayrılık Kuramı”nı ortaya koymuştur. Ayrılık Kuramı'nın savunucularına göre dil kullanımları arasında "daha iyi” ya da "daha kötü" biçiminde bir ayrım gözetilmesi uygun değildir. Aynı biçimde "eksiksiz" ve "eksiği olan" ya da "yeterli" ve "yetersiz" dil türleri biçiminde bir sınıflandırmayı kabul etmek mümkün değildir. Dil kullanımlarının ve türlerinin hepsi, ayrı ayrı, kendine özgü birer dizgeyi yansıtmaktadırlar. Bu nedenle dil türlerinden biri, ötekinden “daha iyi” olarak değerlendirilemez (İmer, 1990: 43).

\subsection{Dil Varyasyonu}

Dünya'daki doğal dillerin hiçbiri konuşma sırasında sabit değildir, aksine çeşitlilik göstermektedir. Dil konuşurları; bölgesel yerleşim, yaş, eğitim, meslek, 
cinsiyet vb. değişkenlere göre birbirinden farklı dil kullanımları gerçekleştirmektedir (Dağabakan, 2012: 94-95).

Doğal dil konuşurlarının mutlaka ait oldukları bir ya da birden fazla toplumsal katman bulunmaktadır. Toplumdaki bir bireyin edinilmiş statüleri (yaşlı, genç, erkek, kadın, siyah, beyaz), kazanılmış statüleri (baba, anne, öğretmen) vardır. Ayrıca bireylerin birden fazla statüsünün olması da oldukça doğaldır. Örneğin, 70 yaşında olup kızı olan bir kadın diş doktoru; yaşlı, kadın gibi edinilmiş ve anne, diş doktoru gibi kazanılmış statülere sahip olabilir.

Toplumdaki katmanlarda çeşitli değişkenlere göre ortaya çıkan farklı dil kullanımları dil varyasyonu terimini doğurmuştur. Toplumdilbilimcilerin farklı ölçütlere göre sınıflandırdığı dil varyasyonunu Norbert Dittmar (aktaran İmer, 1990: 44) dört başlıkta sınıflandırmaktadır:

a. Ölçünlü (Alm. Standard-Varietäten),

b. Bölgesel (Alm. Regionale Varietäten),

c. Toplumsal (Alm. Soziale Varietäten),

ç. İşlevsel (Alm. Funktionale Varietäten).

Öte yandan Busmann (2006: 1260) dil katmanlarının ortaya çıkış nedenlerini;

a. Mekânsal farklılıklar (örneğin ağızlar),

b. Sınıfa özgü dilsel davranışa bağlı,

c. Durumsal etkenler (örneğin resmî veya gayriresmî konuşma bağlamları),

ç. Dil edinimi aşamaları,

d. Dil ilişkileri,

e. Picin ve kreol dillerinin gelişmesi

biçiminde 6 kategori altında sıralayarak dil varyantlarını sınıflandırmaktadır.

\subsection{Sosyoekonomik Düzeylere Göre Dil Kullanımları}

Bu çalışmanın çıkış noktasını toplumsal varyasyon oluşturmaktadır. Dilin sosyoekonomik katmanlara göre nasıl değişkenlik gösterdiğini araştırmak ise bu çalışmanın ana amacıdır. Bu değişkenliği ortaya koyabilmek için öncelikle bir sosyoekonomik endeksi sunmak gerekmektedir. Alanyazında sosyoekonomik endeksleri farklı biçimde ele almış araştırmacılar vardır. Örneğin Trudgill (1974), Norwich üzerine yaptığı çalışmada, altı düzeye dayalı bir toplumsal sınıf endeksi oluşturmuştur. Bu toplumsal sınıf değişkenleri şunlardır:

a. meslek, 

b. babanın mesleği,
c. gelir,
ç. eğitim,
d. muhit (çevre),
e. barınma (konut değeri, kirası) (Ash: 2013, 356).

Filadelfiya'da Dil Değişimi ve Türleri Araştırması (The Study of Linguistic Change and Variation in Philadelphia) adlı çalışmasında Labov (2001, 60-61) sosyoekonomik endeks için bireylerin mesleği, eğitim düzeyi-türü ve yerleşim yeri olmak üzere üç ana başlık altında altı dereceli bir ölçek kullanmıştır.

\begin{tabular}{|c|c|c|}
\hline ЕĞітім & MESLEK & $\begin{array}{l}\text { İKÂMETGÂH } \\
\text { (KiRA VB.) }\end{array}$ \\
\hline $\begin{array}{l}\text { 6. Üniversite lisansüstü mezunu } \\
\text { (hukuk, tıp gibi mesleğe yönelik } \\
\text { bölümlerden mezun) }\end{array}$ & $\begin{array}{l}\text { 6. Profesyonel, büyük firmanın } \\
\text { sahibi veya yöneticisi }\end{array}$ & 6. 25.000 ABD doları + \\
\hline 5. Üniversite-lisans mezunu & 5. Beyaz yakalı mal sahibi, yönetici & $\begin{array}{l}\text { 5. 20.000-24.900 ABD } \\
\text { doları }\end{array}$ \\
\hline 4. Yüksek okul - önlisans & $\begin{array}{l}\text { 4. Beyaz yakalı - tüccar, ustabașı, } \\
\text { satıcı }\end{array}$ & $\begin{array}{l}\text { 4. } 15.000-19 \cdot 900 \text { ABD } \\
\text { doları }\end{array}$ \\
\hline 3. Lise mezunu & 3. Mavi yakalı - vasıflı & $\begin{array}{l}\text { 3. } 10.000-14.900 \quad A B D \\
\text { doları }\end{array}$ \\
\hline 2. Lise terk & 2. Mavi yakalı - vasıfsız & 2. 5.000-9.900 ABD doları \\
\hline 1. İlköğretim & 1. İșsiz & 1. $0-4.900 \mathrm{ABD}$ doları \\
\hline
\end{tabular}

\section{Tablo 1. Labov'un Sosyoekonomik Endeks Sınıflandırması}

Tablo 1'de Labov'un kullandığı sosyoekonomik endeks gösterilmiştir. Buna göre Labov; eğitim, meslek ve yıllık kira bedeli arasındaki kıyaslamalarla toplumsal sınıf farklılığı ortaya koymuştur. Bu ana sütunlar arasındaki ilişkiden doğan yapıda istisnalar olması da son derece doğaldır. Zira ilköğretim düzeyinde eğitime sahip olmakla birlikte ikâmetgâh değeri yüksek bir konutta yaşayan, aynı zamanda kendine ait bir şirkette üst düzey yönetici olan bireye Türkiye'de rastlamak olası bir durumdur. Tam tersi biçimde lisansüstü eğitim yapmış ancak düzenli bir işi olmayan ve dolayısıyla barınma için çok düşük bir bütçesi olan bireyle karşılaşmak da mümkündür. Bununla birlikte yüksek veya düşük fiyatlı otomobillere sahip olmanın toplumsal sınıf göstergesi olarak kabul edildiğini ortaya koyan çeşitli çalışmalar (Guofang ve Jianli, 2008; Dittmann ve Goebel, 2010; Wang ve Quan, 2018) alanyazında mevcuttur. Üstelik Sweet (2010: 2031) sağlık ve kültür değişkenlerinin toplumsal sınıfları nasıl yansıttığını ele aldığı kapsamlı çalışmasında ortaya koyduğu "toplumsal sınıf göstergeleri ve ağırlıklı ortalama puanları tablosunda” iyi (yüksek fiyatlı) bir otomobile sahip olmanın üst sınıflara ait bir toplumsal gösterge olduğunu net olarak ifade etmektedir. 


\subsection{Sosyoekonomik Farklılıklardan Hareketle Yapılmış Bazı Dil} Çalışmaları

Bernstein, Labov ve Trudgill gibi toplumdilbilim alanında öncül çalışmaların sahibi olan bu araştırmacılar sosyoekonomik katmanlara göre çeşitli araştırmalar yapmışlardır. Hatta toplumdilbilim alanında çeşitli kuram ve yaklaşımların ortaya çıkmasını sağlayan ilk çalışmalar genellikle sosyoekonomik sınıf farklarının dil kullanımındaki etkisini ele almıştır.

Bernstein (1958) Kavrayışı Belirleyen Bazı Toplumsal Etkenler (Some Sociological Determinants of Perception) çalışmasında orta sınıfların çocukları ile işçi sınıfının çocuklarındaki akademik başarı düzeyini incelerken dil yeterliklerine ilişkin tespitlerde bulunmuştur. Bernstein (1959) eksiklik kuramını ortaya attığı çalışmasında işçi sınıfı çocuklarının okullardaki akademik başarısızlığının nedenlerini araştırırken bu durumu etkileyen önemli etkenlerden birinin toplumsal katmanlar ve bu katmanlara özgü farklılıklar olduğunu ortaya koymuştur. Bernstein (1959) çalışmasında kamu dilinin ve kurallı dilin karakteristik özelliklerini belirtmiştir.

Labov (1966/2006) sosyoekonomik statü ile telaffuz arasındaki ilişkiye odaklandığı Nev York şehrinde Ingilizcenin Toplumsal Tabakalaşması (The Social Stratification of English in New York City) adlı toplumsesbilgisi çalışmasında; alışveriş merkezlerinin düzeyleri, çalışanların hangi reyonda çalıştıkları, yaşları, görevleri, ırkları, yabancı ya da bölgesel aksana sahip olup olmadıkları vb. değişkenleri dikkate almıştır. Labov (2006: 42) üç farklı sosyoekonomik toplumsal sınıfı temsil eden üç mağazada -üst (highest ranking) (Saks Fifth Avenue), orta (middle ranking) (Macy's) ve alt (lowest ranking) (S. Klein)araştırmasını gerçekleştirmiştir.

Trudgill, Labov'un çalışmasına benzeyen bir çalışma yapmıştır. Trudgill (1974) kent ağızbilim (urban dialectology) olarak sınıflandırılan çalışmasında İngiltere'nin Norwich kentinde yaşayanların /n/ ve /ñ ünsüzlerini telaffuzlarını incelemiştir. Söz konusu çalışmadaki hedef kişilerin eğitim düzeyi, ebeveynlerinin eğitim düzeyleri, yaşadıkları muhit, meslekleri, gelir düzeyleri ve gayrimenkul sahibi olup olmadıkları gibi toplumsal sınıf değişkenlerini gözetmiştir.

Türkiye'de de toplumsal katmanlar arasındaki dil kullanımlarının farklılıklarıyla ilgili çeşitli araştırmalar yapılmıştır. Özellikle sosyoekonomik farklılıkların dil kullanımındaki farklılığına odaklanıp hazırlanmış çalışmalar vardır.

Yapılan alanyazın taramasında Türkiye'de rastlanan ilk çalışmayı yapan Yılmaz (1974: 31), üç farklı toplumsal katmana mensup öğrencilerin dil kullanımı üzerinde yaptığı eğitimbilim ve toplumdilbilim temelli araştırmasında farklı toplumsal katmanlarda doğan çocukların dil kullanımlarını ebeveynlerine nasıl benzettiklerine; alt, orta ve üst toplumsal katmanlarda ebeveynlerden dil ediniminin ne şekilde gerçekleştiğine odaklanmış ve orta ve üst toplumsal 
katmanlardan gelen çocukların dil kullanım çeşitliliğinin arttığı sonucuna ulaşmıştır.

İmer (1990), Ankara'nın farklı semtlerindeki farklı toplumsal katmanlardan ilkokul öğrencilerine aynı konu ile ilgili bir yazı çalışması yaptırmıştır. Çalışmada İmer (1990: 61) anne ve babanın mesleği, öğrenim durumu, ailenin ortalama aylık kazancı, ailece nereli oldukları ve ne zamandan beri Ankara'da bulundukları gibi toplumsal katman göstergelerine göre hareket ederek çalışmada üst, orta ve alt katman gelir gruplarından çocukların dil kullanımlarını incelemiştir. Çalışma sonucunda İmer, üst katmandaki öğrencilerin ölçünlü Türkçeye en yakın dil özelliklerine sahip olduklarını, orta katmandaki öğrencilerin ölçünlü dile daha yakın bir dil kullandıklarını, alt katmandaki çocukların ise konuştukları gibi yazma ve ebeveynlerinden edindikleri ağız özelliklerini ölçünlü dile aktarma eğiliminde olduğunu tespit etmiştir (İmer, 1990: 135-137).

Büyükkantarcıoğlu (1992: 227); alt, orta ve üst sosyoekonomik katmanlardan gelen ilkokul üçüncü ve beşinci sınıf öğrencilerinin sahip olduğu söz varlığı değişkenliğini irdeleyen bir çalışma yapmıştır.

Çolak (2003) sosyoekonomik özellikleri bakımından farklılık gösteren Ankara'daki iki farklı lisenin öğrencilerine yazma becerisine dayalı yaptırdığı çalışmasında öğrenciler arasındaki dil kullanım farklılıklarını ortaya koymuştur. Çolak önceki çalışmasına göre daha hacimli ve kapsamlı öteki çalışmasında (2008) söz varlığının cinsiyetlerle ve toplumsal katmanlarla ilişkisini incelemiștir.

Eker (2007) /e/ sesbiriminin altsesbirimleri ile sosyoekonomik statü grupları arasında ilişki bulunup bulunmadığını, bulunuyorsa bu ilişkinin ve niteliklerinin neler olduğunu ortaya koymak, ölçün dışı altsesbirimlerin kullanımına karşı alınan tutumları araştırmak üzere, bir vakıf ve bir devlet üniversitesindeki öğrencilerle toplumsesbilgisi araştırması yapmıştır. Eker (2007: 246), yaptığı araştırmadaki katılımcıların ailelerinin toplam gelirleri olarak "daha üst (5001 YTL ve üstü) / üst (2501-5000 YTL) / orta üstü (1501-2500 YTL) / orta (501-1500 YTL) / düşük (500 YTL veya daha az)" biçiminde bir sosyoekonomik endeksi kabul etmiştir.

Şengül (2009), Türkçe eğitimi ile toplumdilbilimi ilişkilendirdiği çalışmasında farklı sosyoekonomik katmanlardan gelen öğrencilerin okullarda ölçünlü Türkçe öğrenme süreçlerinde ülke genelinde çalışmalar yapılması ve bu konuda ulusal olarak ortak hareket edilmesi gerekliliğine dikkat çekmiştir.

\subsection{Sosyoekonomik Farklılıklar ve Dil Kullanımı Arasındaki ilişsiden Ortaya Çıkan Ölçekler}

Alanyazında toplumsal katmanlar ve dil kullanımı arasındaki farklılıkları dile getirerek farklılıklar şablonunu oluşturan ilk çalışma Bernstein'a aittir. Bernstein'a (1959: 311) göre kamu dilinin (public language) karakteristik özellikleri: 
“1. Kısa, dilbilgisel açıdan basit, genellikle bitirilmemiş tümceler, etken eylem biçimlerinin yeğlendiği zayıf söz dizimsel yapılar kullanılır.

2. Az sayıdaki bağlaç (“öyleyse”, “sonra”, “ve”, “çünkü” vb.) yinelenerek kullanılır.

3. Kısa emir ve sorular sık kullanılır.

4. Önadlar ve belirteçler sabit ve sınırlı olarak kullanılır.

5. Kişisiz adıllar özne olarak sık kullanılmaz "he", "şhe” gibi kişiye işaret eden adıllar tümcede özne olarak sık kullanılmazken “one”, “it” gibi kişiye işaret etmeyen adılların tümcede özne olarak kullanılabilir.

6. Tümceler, konuşucu ve dinleyici arasında sempatik bir döngü oluşturacak biçimde örtük sorular olarak düzenlenir. (Yok, canım!, Bu normal, değil mi?, Ben inanmazdım.)

7. Bir olayın izahı genellikle neden olarak da sonuç olarak da kullanılır veya daha doğrusu, neden ve sonuç kategorik bir ifade üretmek için karıştırılır. Örneğin "Sana söylediğimi yap.", "Sıkı dur.", "Dışarı çıkmıyorsun.", "Kes şunu".

8. Bir grup deyimin ve kalıp ifadenin bireyin tercihine göre seçmesine sıkça rastlanır.

9. Sembollerle ifade etme düşük miktarda yapılır.

10. Bireysel nitelikler ve özellikler tümce yapısında örtüktür; bu nedenle örtük bir anlam dilidir."

Bernstein'a (1959: 312) göre kurallı (formal) dilin bazı karakteristik özellikleri:

“1. Söylenenler, doğru bir dilbilgisel düzenle ve söz dizimiyle düzenlenmiştir.

2. Mantıksal değişiklikler ve vurgulamalar; dilbilgisel açıdan karmaşık tümce yapılarıyla, özellikle yan tümcelerle ve çeşitli bağlaçlarla sağlanmaktadır.

3. Mantıksal ilişkileri gösteren ilgeçler sıkça kullanılırken, zamansal ve uzamsal yakınlığı gösteren ilgeçler de sık kullanılır.

4. Kişisiz adıllar [biri, he, she adıllarından ziyade it "o") sık kullanılır. 
5. Önad ve belirteçler ayırt edici biçimde seçilir.

6. Bireysel nitelik ve özellikler, tümce içindeki yapı ve ilişkiler aracılığıyla sözlü olarak apaçı ifade edilir.

7. Dilsel biçimle oluşturulan dışavurumcu sembolizm, söylenen ifadeye mantıksal anlamdan ziyade duygusallık verir.

8. Deneyimin düzenli biçimde anlatılması için karmaşık bir kavramsal hiyerarşinin doğasında bulunan olasılıklara işaret eden bir dil kullanılır."

Buna göre Bernstein iki toplumsal katman ile çeşitli dil kullanımları arasında ilişkisel durumları tespit etmiştir. Bernstein'ın dil kullanım tespitlerinin söz dizimi, söz varlığı, edimbilimsel vb. farklı dil düzlemlerinde gerçekleșen boyutları vardır.

\begin{tabular}{|c|c|c|c|}
\hline \multirow{5}{*}{ а) söz Diziмi } & Ölçüt & Geniș Kod & Dar Kod \\
\hline & Tümce yapısı & Karmașık & Basit \\
\hline & Tümce uzunluğu & Nispeten uzun tümceler & $\begin{array}{l}\text { Nispeten kısa } \\
\text { tümceler }\end{array}$ \\
\hline & Tümce biçimi & Değișken & Basmakalıp \\
\hline & ilgeçler & Oldukça sık & Oldukça nadir \\
\hline \multirow[t]{2}{*}{ b) SÖZ VARLIĞı } & Çeşitlilik & Çok & $\mathrm{Az}$ \\
\hline & Önadlar, belirteçler & Farklı, çok sayıda & Sabit, sınırlı \\
\hline \multirow{3}{*}{$\begin{array}{l}\text { c) EDIMBiLimSEL } \\
\text { veya BíLișSEL íLGi }\end{array}$} & Duygusallık & Dolaylı & Doğrudan \\
\hline & Sorular, emirler & Oldukça nadir & Oldukça sık \\
\hline & Düșünme araları & Sık & Nadir \\
\hline
\end{tabular}

\section{Tablo 2. Bernstein'ın Kodları (Seçili Özellikler)}

Tablo 2'de Veith'in (2005: 103), Bernstein'ın çalışmasında iki ayrı bölümde listelediği karakteristik özelliklerden yola çıkarak dar ve geniş kodun değişkenlerini tablolaştırıp sunduğu özellikler vardır. Tabloda Veith, dil düzlemlerine ilişkin başlıkları görselleştirmiş, Bernstein'a göre daha açık hâle getirerek bir bakıma sözel veriyi bir ölçek görünümünde sunmuştur. Bu çalışmanın bulgular kısmında elde edilen bilgiler, Veith'in tablosu ile Bernstein'ın listelediği özelliklerin harmanlanmasıyla oluşturulmuştur.

\section{Amaç}

$\mathrm{Bu}$ çalışmanın temel amacı, doğal dil konuşurlarının ait oldukları farklı sosyoekonomik katmanlar ve dil kullanımları arasında bir ilişki olup olmadığını tespit etmek; varsa bu ilişkinin hangi dil kullanım özelliklerinde görüldüğünü belirlemektir.

Ayrıca bu çalışmada aşağıdaki araştırma sorularını cevaplandırmak amaçlanmıştır: 
- Türkçede sosyoekonomik katman ile dil kullanımı arasında bir ilişki var mıdır?

- Farklı sosyoekonomik katmanlardaki bireylerin dil kullanımında ne gibi farklılıklar görülmektedir?

- Dil kullanııılarının, içeriğini özgün olarak ürettiği satılık otomobil ilanlarında otomobil değer aralıklarından hareketle sosyoekonomik katmanlardaki dil kullanımı görünümü nasıldır?

- Yüksek veya düşük gelir/satın alma gücüne sahip kişilerin oluşturduğu metinlerdeki Türkçe kullanımlarındaki değiş̧kenler nelerdir?

\section{Yöntem}

Bu çalışmayı gerçekleştirmek için izlenen basamaklar şöyledir.

\subsection{Birinci Basamak: Dil Verisi İçin Kullanılacak Kaynağın Tespiti}

$\mathrm{Bu}$ çalışmanın ana amacı, doğal dil konuşurlarının ait oldukları sosyoekonomik katmandaki dil farklılıklarını tespit etmek olduğu için çalışmada kullanılacak dil verisinin doğrudan doğal dil konuşuruna ait olması gerekmektedir. Elektronik ticaret olanağı sağlayan internet sitelerinin bazılarında üretilmiş metinlerin büyük bir bölümü, o konuda uzmanlaşmış satıcı tarafından oluşturulmaktadır. Dolayısıyla bu tür bir dil verisi belirli bir meslek grubuna ait olan bir yapı ile ortaya çıkmakta ve dil konuşurlarındaki çeşitliliği tam anlamıyla sağlayamamaktadır.

Sosyoekonomik katmanlardaki dil kullanımına dair, gerçek kişilerin oluşturdukları içerikleri yani doğal dil verilerinin barındırmasından dolayı kopya ilanlar, sadece uzman kişinin yazdığı metinler vb. kullanımlardan kaçınmak amacıyla yalnızca satıcının bizzat metin oluşturduğu tüketicinden tüketiciye (C2C: customer to customer) e-ticaret olanağı sağlayan bir internet sitesi tercih edilmiștir.

www.alibaba.com (Çin-1999), www.ebay.com (ABD-1995), www.gittigidiyor.com (Türkiye-2001), www.letgo.com (ABD-2015), www.sanalpazar.com (Türkiye-2009), www.dolap.com (Türkiye-2016) vb. tüketiciden tüketiciye e-ticaret olanağı sağlayan internet siteleri arasında emlak, vasıta, alışveriş, iş makineleri, sanayi, yedek parça-aksesuar-donanım ve tuning, hizmetler, iş ilanları, hayvanlar âlemi, özel ders verenler ve yardımcı arayanlar vb. için içerik sunan sahibinden.com (Türkiye-2000), gelişmiş altyapı sistemiyle, çok sayıdaki sunucusuyla, İstanbul ve Ankara'da bulunan 2 adet veri merkeziyle Türkiye'nin en büyük elektronik ticaret ve ilan platformu olma özelliğini taşımaktadır (Şahin ve Kaya, 2019: 263). Türkiye'de bilinirliği yüksek olup kurumsal yapısı oturmuş köklü bir yapıya sahip olması gibi nitelikleri göz önünde 
bulundurularak tüketiciden tüketiciye hizmet veren www.sahibinden.com ${ }^{4}$ adlı internet sitesi araştırmanın veri setinin temin edileceği kaynak olarak kabul edilmiştir.

Bu internet sitesindeki tüm kategorileri ele almak, makale düzeyindeki bir çalışmayı aşacağından ve insanların alım gücünü temsil eden ve gelir düzeylerini yansıtan bir meta olduğundan veri seti yalnızca "vasıta" kategorisi altındaki “otomobil” ilanlarıyla sınırlı tutulmuştur.

Öte yandan bu platforma farklı illerden ilan vermek mümkün olduğu için, ilan metinlerindeki farklı illere veya bölgelere özgü ağız özellikleri ile ilgili değişkenlerin etkisini en aza indirmek amacıyla ilan adresindeki il seçeneği Eskişehir ili ile sınırlı tutulmuştur.

Son olarak uygulanan sınırlandırmada ise meslek dili ile ilgili değişkenleri ortadan kaldırmak, kopya ilanlar, sürekli tekrar eden dil yapıları vb. kullanımlardan kaçınmak için "galeriden" ve "yetkili bayiden" olan ilanlar kapsam dışı bırakılarak doğal dil kullanımı verileri elde edebilmek amacıyla yalnızca "sahibinden" olacak şekilde verilmiş ilanlar değerlendirmeye alınmıştır. Arama yapılırken başka bir sınırlandırma ölçütü kullanılmamıştır.

\section{2. íkinci Basamak: Veri Setinin (Derlemin) Olușturulması}

Yukarıda ayrıntılarıyla anlatılan sınılandırmalar uygulanarak www.sahibinden.com adlı internet sitesinde 31 Aralık 2020 tarihinde, saat 16.31 ila 18.04 arasında yapılan aramalar sonucu toplamda 2.568 ilan olduğu tespit edilmiştir.

6 farklı sosyoekonomik katmanı temsil edebilecek otomobil değer aralıklarını belirleyebilmek amacıyla arama sonucu ulaşılan 2.568 ilan 6'ya bölünmüştür. Bu işlemin sonucunda 428'er ilan elde edilmiştir. Bu bölme işlemi sonucu ortaya çıkan değer aralıkları ise şöyledir:
1. 0-51.999,
2. 52.000-79.999,
3. 80.000-111.999,
4. 112.000-142.999,
5. 143.000-195.999,
6. 196.000 ve üzeri

Ancak, sosyoekonomik katmanların en alt ve en üst düzeylerindeki dil kullanım durumlarını ortaya koymak, daha sağılıklı ve dengeli bir karşılaştırma yapabilmek amacıyla sosyoekonomik katmanları belirleyen fiyat aralıkları aşağıdaki biçimde belirlenmiştir.

En alt katman: 0-19.999,

Alt katman: 20.000-49.999,

Orta alt katman: 50.000-99.999

\footnotetext{
4 sahibinden.com, gayrimenkul, vasıta, alışveriş ürünleri ve hizmetler gibi birçok kategoride ilan ve e-ticaret işlemlerinin yapıldığı çevrimiçi (online) bir platformdur ( https://www.sahibinden.com/kurumsal/hakkimizda/ Erişim Tarihi: 12.11.2020).
} 
Orta katman: 100.000-249.999,

Üst katman: 250.000-499.999,

En üst katman: 500.000 ve üzeri

Aramalar yapılırken daha önce kullanılan sınırlandırmalar dâhilinde belirlenen fiyat aralıklarında ayrı ayrı aramalar yapılmıştır. Bu aramalar sonucunda;

(0-19,999) (20.000'in altı) fiyat aralığında yapılan aramada 25 ilan; 20.00049.999 fiyat aralığında yapılan aramada 355 ilan; 50.000-99.999 fiyat aralığında yapılan aramada 687 ilan; 100.000-249.999 fiyat aralığında yapılan aramada 1.208 ilan; 250.000-499.999 fiyat aralığında yapılan aramada 264 ilan; 500.000 ve üzeri fiyat aralığında yapılan aramada 29 ilan bulunmuştur.

İlan tarihine göre “önce en yeni ilanlar” sıralanmış ve her katman için 25'er ilan seçilerek veri seti ${ }^{5}$ oluşturulmuştur.

Tümce hükmünde açıklaması bulunmayan (tümce değerinde olmayan, sadece sözcükten oluşan) ilanlar değerlendirilmeye alınmamış, bir sonraki ilan kapsama dâhil edilmiştir.

Arama sonucu eşleşen ilanlar Word dosyasına kopyalanmış, bu ilanların yalnızca açıklama bölümleri incelemeye dâhil edilmiştir. Açıklama bölümlerinde yer alan ancak tümce niteliği taşımayan ifadeler (maddelendirilmiş özellikler vb.) araştırma kapsamının dışında bırakılmıştır.

\section{3 Üçüncü Basamak: Oluşturulan Derlemdeki Dil Verilerinin Etiketlenmesi}

Veith'in (2005: 103) Bernstein'dan (1959: 311-312) hareketle toplumsal katmanlarda dil kullanımını karşılaştırmalı olarak verdiği tablosu (Tablo 2) esas alınarak dil kullanım özellikleri belirlenmiştir. Bu tablodan hareketle söz dizimi ile ilgili olarak tümce yapısını, tümce uzunluğunu, tümce biçimini ve ilgeç kullanımını; söz varlığı ile ilgili olarak sözcük çeşitliliğini, önadları ve belirteçleri; edimbilimsel özellikler ile ilgili olarak soru kullanımını ve emir kullanımını belirlemek üzere ilan açıklamalarında etiketlemeler yapılmıştır.

Konuşma diline özgü metinler üzerinde bir inceleme yapılmadığından bu tabloda yer alan duygusalık ve düşünme araları ölçütleri araştırma kapsamına dâhil edilmemiştir. Etiketleme yapılırken bahsi geçen tabloda yer alan özelliklere ek olarak yazım yanlışları, etken/edilgen çatılı kullanımlar, eylemsiler (ortaçlar, ulaçlar, ad-eylemler), bağlaçlar, adıllar, ünlemler, yüklemin türüne göre tümce

\footnotetext{
5 0-19.999 fiyat aralığında (en alt katmanda) toplam 25 ilan bulunduğundan, çalışmanın sonuçlarında dengeli bir görünüm elde etmek amacıyla her katman aralığından toplam 25'er ilan değerlendirmeye alınmıştır. Biber (1990) 1.000 sözcüklük bir derlemin; adıllar, zamanlar gibi dilbilgisel ögelerle ilgili yapılan çalışmalarda güvenilir sonuçlar sağlayacak kadar yeterli olduğunu belirtmektedir. Dolayısıyla bu çalışma için oluşturulan derlemin 7.063 sözcükten oluşması çalışmanın bulgularının geçerliğini artııır durumdadır.
} 
türleri, kısaltma kullanımları, yabancı söz kullanımları, noktalama ile ilgili yanlışlar, büyük/küçük harf kullanımıyla ilgili yanlışlar, büyük/küçük harf kullanım tercihleri, yüklemin yerine göre tümce türleri (devrik/kurallı), nezaket gösteren biçimbirimler de etiketlenmiştir.

\subsection{Dördüncü Basamak: Verilerin Raporlanması}

Çalışmada etiketlenen verilerden hareketle sosyoekonomik katmanlar arasındaki dil kullanımıyla ilgili benzerlikler ya da farklılıklar gösterilmiştir. Yapılan etiketleme ve listeleme işlemlerinden sonra farklı dil kullanım özelliklerine ait elde edilen sayısal bulgularda, belirlenen her bir fiyat aralığındaki sonuçlar istatistiksel olarak karşılaştırılmış ve (varsa) kümelenmeler ortaya konmuştur. Bulgular çerçevesinde hangi özelliklerde anlamlı farkların ortaya çıktığı, hangi özelliklerin sosyoekonomik katmanlar arasında gruplanmalar oluşturduğu, hangi özelliklerin daha önce alanyazında ortaya konan bilgilerle benzerlik ya da farklılık gösterdiği tartışılmıştır.

\section{Bulgular ve Tartışma}

\subsection{Söz Dizimi ile İlgili Özellikler}

Dar kod ve geniş kodun özelliklerinin belirlenmesi için söz dizimi ile ilgili olarak Veith (2005: 103), Bernstein'dan (1959) hareketle tümce yapısı, tümce uzunluğu, tümce biçimi ve tümcede yer alan ilgeçleri ölçüt olarak kullanmıştır. Bunlara ek olarak bu çalışmada örneklemi oluşturan metinlerde edilgen çatılı eylem kullanımı, yüklemin türüne göre tümceler (ad tümcesi/eylem tümcesi), yüklemin yerine göre tümceler (kurallı tümce/devrik tümce) ve eylemsi kullanımı (ortaçlar, ulaçlar ve ad-eylemler) da değerlendirmeye dâhil edilmiştir. Vetih'in (2005) söz dizimi başlığı altında yer verdiği ilgeç kullanımı, bu çalışmada söz varlığı başlığında ele alınmıştır. Sosyoekonomik katmanlarda görülen söz dizimi ile ilgili özellikler şunlardır: 


\subsubsection{Tümce Sayısı}

\begin{tabular}{|c|c|c|c|c|c|c|}
\hline $\begin{array}{l}\text { Dilsel } \\
\text { Kodlar }\end{array}$ & $\begin{array}{l}\text { Toplumsal } \\
\text { Sinıflar }\end{array}$ & $\begin{array}{l}\text { Sosyoekonomik } \\
\text { Katmanlar }\end{array}$ & $\begin{array}{l}\text { Otomobil } \\
\text { Değer Aralığı } \\
(\mathrm{TL})\end{array}$ & $\begin{array}{l}\text { Toplam } \\
\text { Tümce } \\
\text { Sayısı }\end{array}$ & $\begin{array}{l}\text { Toplama } \\
\text { Göre Tümce } \\
\text { Oranı }\end{array}$ & $\begin{array}{l}\text { İlan } \\
\text { Sayısı }\end{array}$ \\
\hline \multirow{3}{*}{$\begin{array}{l}\text { Dar } \\
\text { Kod }\end{array}$} & \multirow{2}{*}{ Alt Sınıf } & En Alt Katman & $0-19.999$ & 164 & $\$ 12,51$ & 25 \\
\hline & & Alt Katman & $\begin{array}{l}20.000- \\
49.999\end{array}$ & 246 & 818,76 & 25 \\
\hline & \multirow{2}{*}{ Orta Sınıf } & Orta Alt Katman & $\begin{array}{l}50.000- \\
99.999\end{array}$ & 225 & $\$ 17,16$ & 25 \\
\hline \multirow{3}{*}{$\begin{array}{l}\text { Geniș } \\
\text { Kod }\end{array}$} & & Orta Katman & $\begin{array}{l}100.000- \\
249.999\end{array}$ & 252 & $\$_{19,22}$ & 25 \\
\hline & \multirow{2}{*}{ Üst Sınıf } & Üst Katman & $\begin{array}{l}250.000- \\
499.999\end{array}$ & 208 & $\mathscr{8}_{15}, 87$ & 25 \\
\hline & & En Üst Katman & $\begin{array}{l}500.000 \mathrm{ve} \\
\text { ūzeri }\end{array}$ & 216 & 816,48 & 25 \\
\hline \multicolumn{4}{|c|}{ Genel Toplam } & 1311 & 8100 & 150 \\
\hline
\end{tabular}

\section{Tablo 3. Tümce Sayıları, Dağılımları ve Oranları}

Söz dizimi ile ilgili genel bir değerlendirme yapabilmek amacıyla öncelikli olarak metinlerde yer alan tümce sayıları belirlenmiştir. Tablo 3'te örneklemi oluşturan metinlerdeki katman, sınıf ve kodlara göre tümce sayıları ve genel toplama göre oranları gösterilmiştir. En fazla tümce sayısı ve oranı orta katmanda, en az tümce sayısı ve oranı ise en alt katmandadır. Tümce sayısı ve oranı alt sınıfta en düşükken üst sınıfta nispeten daha yüksek, orta sınıfta ise en yüksektir. Oransal olarak dar koddaki tümce sayısı oranı toplamı \%48,43 iken geniş koddaki tümce sayısı oranı toplamı \%51,57'dir. Bu noktada geniş koddaki tümce sayısının oransal olarak dar koda göre fazla olduğu görünmektedir. 


\subsubsection{Tümce Uzunluğu}

\begin{tabular}{|c|c|c|c|c|}
\hline $\begin{array}{l}\text { Dilsel } \\
\text { Kodlar }\end{array}$ & $\begin{array}{l}\text { Toplumsal } \\
\text { Sinıflar }\end{array}$ & $\begin{array}{l}\text { Sosyoekonomik } \\
\text { Katmanlar }\end{array}$ & $\begin{array}{l}\text { Otomobil Değer Aralığı } \\
\text { (TL) }\end{array}$ & $\begin{array}{l}\text { Ortalama Tümce } \\
\text { Uzunluğu }\end{array}$ \\
\hline \multirow{3}{*}{$\begin{array}{l}\text { Dar } \\
\text { Kod }\end{array}$} & \multirow{2}{*}{ Alt Sınıf } & En Alt Katman & $0-19.999$ & 4,36 \\
\hline & & Alt Katman & $20.000-49.999$ & 4,96 \\
\hline & \multirow{2}{*}{ Orta Sinıf } & Orta Alt Katman & $50.000-99.999$ & 4,82 \\
\hline \multirow{3}{*}{$\begin{array}{l}\text { Geniş } \\
\text { Kod }\end{array}$} & & Orta Katman & $100.000-249 \cdot 999$ & 6,24 \\
\hline & \multirow{2}{*}{ Üst Sınıf } & Üst Katman & $250.000-499.999$ & 6,02 \\
\hline & & En Üst Katman & 500.000 ve üzeri & 5,58 \\
\hline & & Genel Toplam & & 5,33 \\
\hline
\end{tabular}

\section{Tablo 4. Ortalama Tümce Uzunluklarının Dağılımları}

Tablo 4'te örneklemi oluşturan metinlerde bir tümcenin ortalama kaç sözcükten oluştuğuna ilişkin değerlerin farklı katmanlara göre dağılımları gösterilmiştir. Buna göre en kısa tümce uzunluğu en alt katmanda görülmekteyken en uzun tümce uzunluğu ise orta katmandadır. Üst katmanlara doğru tümce uzunluğunun arttığı ancak en üst katmanda tümcelerin nispeten kısaldığı dikkat çekmektedir. Ortalama tümce uzunluğu orta katmanda en yüksek, en alt katmanda en düşüktür. Bu tabloda dikkat çeken asıl husus ise dar kod ile geniş kod arasında ortalama tümce uzunluğu bakımından belirgin bir fark olduğunun görülmesidir. Bu fark başka özelliklerde de açıkça görülmektedir ve bu nedenle çalışmada dar kod ve geniş kod arasındaki sınır 100.000 TL olarak belirlenmiştir. Dar kodda bir tümce ortalama 4,71 sözcükten oluşmakta iken geniş kodda bir tümce ortalama 5,95 sözcükten oluşmaktadır. Geniş koddaki ortalama tümce uzunluğunun dar koda göre belirgin bir biçimde fazla olduğu ortadadır.

Bernstein'a (1959: 311) göre dar ve geniş kodun belirlenmesi için söz dizimsel bir ölçüt olarak belirlenen tümce uzunluğu bu çalışmada da dar ve geniş kod arasında belirgin farklılık göstermiştir. Geniş kodda nispeten uzun tümceler, dar kodda nispeten kısa tümceler kullanıldığı tespit edilmiştir. 


\subsubsection{Tümce Yapısı}

\begin{tabular}{|c|c|c|c|c|c|c|}
\hline $\begin{array}{l}\text { Dilsel } \\
\text { Kodlar }\end{array}$ & $\begin{array}{l}\text { Toplumsal } \\
\text { Sınıflar }\end{array}$ & $\begin{array}{l}\text { Sosyoekonomik } \\
\text { Katmanlar }\end{array}$ & $\begin{array}{l}\text { Otomobil } \\
\text { Değer } \\
\text { Aralığı (TL) }\end{array}$ & $\begin{array}{l}\text { Karmaşık } \\
\text { Tümce } \\
\text { Sayısı ve } \\
\text { Oranı }\end{array}$ & $\begin{array}{l}\text { Basit Tümce } \\
\text { Sayısı ve } \\
\text { Oranı }\end{array}$ & $\begin{array}{l}\text { Toplam } \\
\text { Tümce } \\
\text { Sayısı }\end{array}$ \\
\hline \multirow{3}{*}{$\begin{array}{l}\text { Dar } \\
\text { Kod }\end{array}$} & \multirow[b]{2}{*}{ Alt Sınıf } & En Alt Katman & $0-19.999$ & $49(\% 29,88)$ & $115(\$ 70,12)$ & 164 \\
\hline & & Alt Katman & $\begin{array}{l}20.000- \\
49.999\end{array}$ & $79(\% 32,11)$ & $167(\$ 67,89)$ & 246 \\
\hline & \multirow{2}{*}{ Orta Sinıf } & Orta Alt Katman & $\begin{array}{l}50.000- \\
99.999\end{array}$ & $60\left(8_{26} 67\right)$ & $165(873,33)$ & 225 \\
\hline \multirow{3}{*}{$\begin{array}{l}\text { Geniş } \\
\text { Kod }\end{array}$} & & Orta Katman & $\begin{array}{l}100.000- \\
249.999\end{array}$ & $102(\% 40,48)$ & $150\left(8_{59,52}\right)$ & 252 \\
\hline & \multirow{2}{*}{ Üst Sınıf } & Üst Katman & $\begin{array}{l}250.000- \\
499.999\end{array}$ & $82(839,42)$ & $126(\% 60,58)$ & 208 \\
\hline & & En Üst Katman & $\begin{array}{l}500.000 \mathrm{ve} \\
\text { üzeri }\end{array}$ & $62\left(\gamma_{2} 8,70\right)$ & $154(\% 71,30)$ & 216 \\
\hline \multicolumn{4}{|c|}{ Genel Toplam } & $434(833,1)$ & $877(866,9)$ & 1311 \\
\hline
\end{tabular}

\section{Tablo 5. Yapısına Göre Tümce Sayıları, Dağılımları ve Oranları}

Tablo 5'te yapısına göre tümcelerin katman, sınıf ve kodlara göre sayısı ve toplam tümce sayılarına göre oranları gösterilmiştir. En yüksek basit tümce sayısı alt katmanda, en düşük basit tümce sayısı orta ve üst katmandadır. Tabloda dikkat çeken başka bir husus ise karmaşık tümce oranının alt katmanlardan üst katmanlara doğru yükselmesi, en üst katmanda ise tekrar düşüşe geçmesidir. Dar kodda karmaşık tümce kullanımı oranı \%29,61 iken geniş kodda bu oran \%36,39'dur. Geniş kodda karmaşık tümce kullanımı dar koda göre belirgin bir biçimde fazladır. Yalnızca en üst katmanda karmaşık tümce kullanımı ortalamanın altındadır.

Bernstein (1959: 311-312) tarafından kamu dilinin karakteristik özelliklerinden birincisi olarak ortaya konan "kısa, dilbilgisel açıdan basit tümceler kullanma" ifadesi ve kurallı dilin (formal language) "mantıksal değişiklikler ve vurgulamalar; dilbilgisel açıdan karmaşık tümce yapılarıyla, özellikle yan tümcelerle ve çeşitli bağlaçlarla sağlanmaktadır” ifadesi ile bu çalışmanın bulguları aynı yöndedir. 


\subsubsection{Tümce Biçimi}

\begin{tabular}{|c|c|c|c|c|c|c|c|}
\hline $\begin{array}{l}\text { Dilsel } \\
\text { Kodlar }\end{array}$ & $\begin{array}{l}\text { Toplumsal } \\
\text { Sinıflar }\end{array}$ & $\begin{array}{l}\text { Sosyoekonomik } \\
\text { Katmanlar }\end{array}$ & $\begin{array}{l}\text { Otomobil } \\
\text { Değer } \\
\text { Aralığı } \\
(\mathrm{TL})\end{array}$ & $\begin{array}{l}\text { Basmakalıp } \\
\text { ifade Sayısı }\end{array}$ & $\begin{array}{l}\text { Toplam } \\
\text { Sözcük } \\
\text { Sayısı }\end{array}$ & $\begin{array}{l}\text { Basmakalıp } \\
\text { Ifadelerin } \\
\text { Toplam } \\
\text { Sözcük } \\
\text { Sayısına } \\
\text { Oranı }\end{array}$ & $\begin{array}{l}\text { Toplama } \\
\text { Göre } \\
\text { Basmakalıp } \\
\text { ifade Oranı }\end{array}$ \\
\hline \multirow{3}{*}{$\begin{array}{l}\text { Dar } \\
\text { Kod }\end{array}$} & \multirow[b]{2}{*}{ Alt Sinıf } & En Alt Katman & $0-19.999$ & 38 & 716 & 85,31 & 831,68 \\
\hline & & Alt Katman & $\begin{array}{l}20.000- \\
49.999\end{array}$ & 47 & 1221 & $\% 3,85$ & $\% 22,97$ \\
\hline & Orta Sınıf & $\begin{array}{l}\text { Orta Alt } \\
\text { Katman }\end{array}$ & $\begin{array}{l}50.000- \\
99.999\end{array}$ & 8 & 1086 & \%o,74 & $\$ 4,42$ \\
\hline \multirow{3}{*}{$\begin{array}{l}\text { Geniș } \\
\text { Kod }\end{array}$} & & Orta Katman & $\begin{array}{l}100.000- \\
249.999\end{array}$ & 42 & 1574 & 82,67 & $\$ 15,93$ \\
\hline & \multirow{2}{*}{ Üst Sınıf } & Üst Katman & $\begin{array}{l}250.000- \\
499.999\end{array}$ & 36 & 1255 & 82,87 & $\$ 17,12$ \\
\hline & & En Üst Katman & $\begin{array}{l}500.000 \\
\text { ve üzeri }\end{array}$ & 16 & 1211 & $x_{1,32}$ & $\$_{7}, 88$ \\
\hline \multicolumn{4}{|c|}{ Genel Toplam } & 187 & 7063 & $\% 2,65$ & $\$ 100$ \\
\hline
\end{tabular}

Tablo 6. Basmakalıp İfade Sayıları, Dağılımları ve Oranları

Tümce biçimi olarak değișken ve basmakalıp ifade kullanımları değerlendirilmiştir. Tablo 6'da örneklemi oluşturan metinlerdeki katman, sınıf ve kodlara göre basmakalıp ifade sayıları ve bunların toplam sözcüklere oranları gösterilmiştir. Görüldüğü gibi en yüksek basmakalıp ifade sayısı alt katmanda, en düşük basmakalıp ifade sayısı ise orta alt katmandadır. Oransal olarak bakıldığında en yüksek basmakalıp ifade oranı en alt katmanda iken en düşük basmakalıp ifade oranı orta alt katmandadır. Basmakalıp ifade oranı alt sınıfta çok yüksekken, orta ve üst sınıfta ise daha düşüktür. Dar kodda basmakalıp ifade oranı toplamı \%59,07 iken geniş kodun basmakalıp ifade oranı toplamı $\%, 40,93$ 'tür. Basmakalıp ifadelerin dar kodda geniş koda oranla çok daha fazla kullanıldığı görülmektedir. Veith'in (2005: 103) tablosundaki ölçütlerden biri de tümce biçimidir. Veith, daralmış kodda basmakalıp, genişlemiş kodda değişken tümce biçimlerinin kullanıldığını belirtmektedir. Bernstein'ın (1959: 311) kamu dili için kullandığı "Bir grup deyimin ve kalıp ifadenin bireye göre tercihine sıkça rastlanır." ifadeleri de bu sonuçları destekler niteliktedir.

Genel olarak metinlerde ilan dili özelliklerinden kaynaklanan ve ilana konu olan meta (otomobil) ile yakından ilgili olan basmakalıp ifadeler kullanılmıştır. Sayısal olarak basmakalıp ifade kullanımında dar ve geniş kod arasında belirgin farklılık görülmekle birlikte aynı zamanda kodlara göre kullanılan basmakalıp ifadelerin farklı olduğu, dar kodda sıkça kullanılan ifadelerin geniş kodda daha az 
kullanıldığı ya da kullanılmadığı, aynı durumun geniş kodda kullanılan ifadeler için de geçerli olduğu gözlemlenmektedir.

\subsubsection{Edilgen Çatılı Eylem Kullanımı}

\begin{tabular}{|c|c|c|c|c|c|c|c|}
\hline $\begin{array}{l}\text { Dilsel } \\
\text { Kodlar }\end{array}$ & $\begin{array}{l}\text { Toplumsal } \\
\text { Sınıflar }\end{array}$ & $\begin{array}{l}\text { Sosyoekonomik } \\
\text { Katmanlar }\end{array}$ & $\begin{array}{l}\text { Otomobil } \\
\text { Değer } \\
\text { Aralığı } \\
(\mathrm{TL})\end{array}$ & $\begin{array}{l}\text { Edilgen } \\
\text { Çatılı } \\
\text { Eylem } \\
\text { Sayısı }\end{array}$ & $\begin{array}{l}\text { Toplam } \\
\text { Eylem } \\
\text { Sayısı }\end{array}$ & $\begin{array}{l}\text { Edilgen } \\
\text { Çatılı } \\
\text { Eylemlerin } \\
\text { Toplam } \\
\text { Eylem } \\
\text { Sayısına } \\
\text { Oranı }\end{array}$ & $\begin{array}{l}\text { Toplama } \\
\text { Göre } \\
\text { Edilgen } \\
\text { Çatılı } \\
\text { Eylem } \\
\text { Oranı }\end{array}$ \\
\hline \multirow{3}{*}{$\begin{array}{l}\text { Dar } \\
\text { Kod }\end{array}$} & \multirow{2}{*}{ Alt Sinif } & En Alt Katman & $0-19.999$ & 27 & 131 & $\not 20,61$ & $\% 11,78$ \\
\hline & & Alt Katman & $\begin{array}{l}20.000- \\
49.999\end{array}$ & 53 & 203 & 826,11 & 814,92 \\
\hline & \multirow{2}{*}{ Orta Sınıf } & Orta Alt Katman & $\begin{array}{l}50.000- \\
99.999\end{array}$ & 41 & 175 & 823,43 & 813,39 \\
\hline \multirow{3}{*}{$\begin{array}{l}\text { Geniș } \\
\text { Kod }\end{array}$} & & Orta Katman & $\begin{array}{l}100.000- \\
249.999\end{array}$ & 70 & 258 & 827,13 & 815,51 \\
\hline & \multirow{2}{*}{ Üst Sınıf } & Üst Katman & $\begin{array}{l}250.000- \\
499.999\end{array}$ & 69 & 208 & $\% 33,17$ & $\$ 18,96$ \\
\hline & & En Üst Katman & $\begin{array}{l}500.000 \\
\text { ve üzeri }\end{array}$ & 73 & 164 & 844,51 & 825,44 \\
\hline \multicolumn{4}{|c|}{ Genel Toplam } & 333 & 1139 & $\$ 29,24$ & 8100 \\
\hline
\end{tabular}

Tablo 7. Edilgen Çatılı Eylem Sayıları, Dağılımları ve Oranları

Tablo 7'de örneklemi oluşturan metinlerdeki katman, sınıf ve kodlara göre edilgen çatılı eylem sayıları ve toplam eylem sayılarına göre oranları gösterilmiştir. En yüksek edilgen çatılı eylem sayısı en üst katmanda, en düşük edilgen çatılı eylem sayısı ise en alt katmandadır. Oransal olarak bakıldığında en düşük edilgen çatılı eylem oranı en alt katmanda iken en yüksek edilgen çatılı eylem oranı orta katmandadır. Katmanlar arasında edilgen çatılı eylem kullanımının kademeli olarak yükseldiği dikkati çekmektedir. Edilgen çatılı eylem oranı alt sınıfta çok düşükken, orta sınıfta nispeten daha yüksek, üst sınıfta ise en yüksektir. Dar kodda edilgen çatılı eylem oranı ortalaması \%40,09 iken geniş kodda bu oran \%59,91'dir. Geniş koddaki edilgen çatılı eylem oranının dar koda göre belirgin bir biçimde fazla olduğu ortadadır. Çalışmadaki edilgen çatılı eylemlerin kullanımı ile ilgili bulgular Bernstein'ın (1962) bulguları ile benzerlik göstermektedir. Zira Bernstein (1962: 226) da edilgen eylem kullanımının dar ve geniş kod arasında farklılık gösteren değişkenlerden biri olduğunu belirtmiştir. Ayrıca Bernstein'ın (1959: 311) kamu dili için kullandığı “...etken eylem biçimlerinin yeğlendiği zayıf söz dizimsel yapılar kullanılır” ifadesi de bu çalışmanın bulguları ile örtüşmektedir. 
4.1.6. Yüklemin Türüne Göre Tümceler

\begin{tabular}{|c|c|c|c|c|c|c|}
\hline $\begin{array}{l}\text { Dilsel } \\
\text { Kodlar }\end{array}$ & $\begin{array}{l}\text { Toplumsal } \\
\text { Sinıflar }\end{array}$ & $\begin{array}{l}\text { Sosyoekonomik } \\
\text { Katmanlar }\end{array}$ & $\begin{array}{l}\text { Otomobil } \\
\text { Değer } \\
\text { Aralığı (TL) }\end{array}$ & $\begin{array}{l}\text { Eylem Tümcesi } \\
\text { Sayısı ve Oranı }\end{array}$ & $\begin{array}{l}\text { Ad Tümcesi } \\
\text { Sayısı ve } \\
\text { Oranı }\end{array}$ & $\begin{array}{l}\text { Toplam } \\
\text { Tümce } \\
\text { Sayısı }\end{array}$ \\
\hline \multirow{3}{*}{$\begin{array}{l}\text { Dar } \\
\text { Kod }\end{array}$} & \multirow{2}{*}{ Alt Sinıf } & En Alt Katman & $0-19.999$ & $86\left(8_{52,44}\right)$ & $78(847,56)$ & 164 \\
\hline & & Alt Katman & $\begin{array}{l}20.000- \\
49.999\end{array}$ & $114(846,34)$ & $132\left(\%_{53}, 66\right)$ & 246 \\
\hline & \multirow{2}{*}{ Orta Sınıf } & Orta Alt Katman & $\begin{array}{l}50.000- \\
99.999\end{array}$ & $96(842,67)$ & $129(\$ 57,33)$ & 225 \\
\hline \multirow{3}{*}{$\begin{array}{l}\text { Geniș } \\
\text { Kod }\end{array}$} & & Orta Katman & $\begin{array}{l}100.000- \\
249.999\end{array}$ & $130(851,59)$ & $122(\$ 48,41)$ & 252 \\
\hline & \multirow{2}{*}{ Üst Sınıf } & Üst Katman & $\begin{array}{l}250.000- \\
499.999\end{array}$ & $99(847,6)$ & $\log (\$ 52,4)$ & 208 \\
\hline & & En Üst Katman & $\begin{array}{l}500.000 \text { ve } \\
\text { üzeri }\end{array}$ & $79(836,57)$ & $137(863,43)$ & 216 \\
\hline \multicolumn{4}{|c|}{ Genel Toplam } & $604(\$ 46,07)$ & $707\left(\%_{53}, 93\right)$ & 1311 \\
\hline
\end{tabular}

\section{Tablo 8. Yüklemin Türüne Göre Tümce Sayıları, Dağılımları ve Oranları}

Tablo 8'de örneklemi oluşturan metinlerdeki katman, sınıf ve kodlara göre yüklemin türüne göre tümcelerin (ad tümcesi/eylem tümcesi) sayıları ve toplam tümce sayılarına göre oranları gösterilmiştir. En yüksek ad tümcesi sayısı en üst katmanda, en düşük ad tümcesi sayısı en alt katmanda; en yüksek eylem tümcesi sayısı orta katmanda, en düşük eylem tümcesi sayısı ise en üst katmandadır. Oransal olarak bakıldığında en yüksek eylem tümcesi kullanım oranının en alt katmanda, en yüksek ad tümcesi kullanım oranının ise en üst katmanda olduğu görülmektedir. En alt katman ve en üst katman arasında yapılacak bir karşılaştırmada belirgin bir biçimde en alt katmanda eylem tümcelerinin, en üst katmanda ise ad tümcelerinin en yoğun olarak kullanılan katmanlar oldukları dikkati çekmektedir. Alt sınıfta ad tümcesi ve eylem tümcesi oranları hemen hemen eşitken orta sınıfta ad tümcelerinin eylem tümcelerine oranla nispeten, üst sınıfta ise belirgin bir biçimde daha fazla kullanıldığı görülmektedir. Dar kodda \%47,15 oranında eylem tümcesi, \%52,85 oranında ad tümcesi; geniş kodda ise $\% 45,24$ oranında eylem tümcesi, $\% 54,76$ oranında ise ad tümcesi kullanılmıştır. Örneklemin geneline bakıldığında metinlerde ad tümcelerinin daha fazla kullanıldı̆̆ı göze çarpmaktadır. Bu durum da örneklemin otomobil ilanlarıla sınırlı olmasıyla açıklanabilir. Zira otomobil gibi bir metanın tarifinde ve özelliklerinin anlatımında doğal olarak ad tümceleri yer alacaktır. 


\subsubsection{Yüklemin Yerine Göre Tümceler}

\begin{tabular}{|c|c|c|c|c|c|c|}
\hline $\begin{array}{l}\text { Dilsel } \\
\text { Kodlar }\end{array}$ & $\begin{array}{l}\text { Toplumsal } \\
\text { Sinıflar }\end{array}$ & $\begin{array}{l}\text { Sosyoekonomik } \\
\text { Katmanlar }\end{array}$ & $\begin{array}{l}\text { Otomobil } \\
\text { Değer } \\
\text { Aralığı (TL) }\end{array}$ & $\begin{array}{l}\text { Devrik Tümce } \\
\text { Sayısı ve Oranı }\end{array}$ & $\begin{array}{l}\text { Kurallı Tümce } \\
\text { Sayısı ve Oranı }\end{array}$ & $\begin{array}{l}\text { Toplam } \\
\text { Tümce } \\
\text { Sayısı }\end{array}$ \\
\hline \multirow{3}{*}{$\begin{array}{l}\text { Dar } \\
\text { Kod }\end{array}$} & \multirow{2}{*}{ Alt Sınıf } & En Alt Katman & $0-19.999$ & $3\left(81,8_{3}\right)$ & $161(\% 98,17)$ & 164 \\
\hline & & Alt Katman & $\begin{array}{l}20.000- \\
49.999\end{array}$ & $6(82,44)$ & $240(\% 97,56)$ & 246 \\
\hline & \multirow{2}{*}{ Orta Sınıf } & Orta Alt Katman & $\begin{array}{l}50.000- \\
99.999\end{array}$ & $4(\% 1,78)$ & $221(\$ 98,22)$ & 225 \\
\hline \multirow{3}{*}{$\begin{array}{l}\text { Geniș } \\
\text { Kod }\end{array}$} & & Orta Katman & $\begin{array}{l}100.000- \\
249.999\end{array}$ & $9(83,57)$ & $243(\% 96,43)$ & 252 \\
\hline & \multirow{2}{*}{ Üst Sınıf } & Üst Katman & $\begin{array}{l}250.000- \\
499.999\end{array}$ & $1(\% 0,48)$ & $207(\% 99,52)$ & 208 \\
\hline & & En Üst Katman & $\begin{array}{l}500.000 \mathrm{ve} \\
\text { üzeri }\end{array}$ & $2(\% 0,93)$ & $214(\$ 99,07)$ & 216 \\
\hline \multicolumn{4}{|c|}{ Genel Toplam } & $25(81,91)$ & $1286(\% 98, \circ 9)$ & 1311 \\
\hline
\end{tabular}

\section{Tablo 9. Yüklemin Yerine Göre Tümce Sayıları, Dağılımları ve Oranları}

Tablo 9'da örneklemi oluşturan metinlerdeki katman, sınıf ve kodlara göre yüklemin yerine göre tümcelerin (devrik tümce/kurallı tümce) sayıları ve toplam tümce sayılarına göre oranları gösterilmiştir. En yüksek devrik tümce sayısı ve oranı orta katmanda, en düşük devrik tümce sayısı ve oranı ise üst katmandadır. Alt sınıfta ve orta sınıfta devrik tümcelerin daha sık olarak kullanıldığı görülüyorken üst sınıfta belirgin bir biçimde devrik tümce kullanım oranı düşmektedir. Dar kodda toplam tümce sayısına göre \%2,02 oranında devrik tümce kullanılmışken geniş kodda \%1,66 oranında devrik tümceye rastlanmıştır. Buradan hareketle her iki kodda da kurallı tümcelerin çok daha yaygın olarak kullanıldığı görülmekle birlikte dar kodda devrik tümce kullanımının geniş koda göre daha fazla olduğu söylenebilir. Bernstein (1959: 312) kurallı dilin en temel özelliği olarak "ifadelerin doğru bir dilbilgisel düzenle ve söz dizimiyle düzenlendiğini” vurgulamıştır. Bu çalışmadaki devrik tümce kullanımıyla ilgili bulgular Bernstein'ı desteklemektedir. 


\subsubsection{Eylemsi Kullanımı}

\subsubsection{Ortaç Kullanımı}

\begin{tabular}{|c|c|c|c|c|c|c|c|}
\hline $\begin{array}{l}\text { Dilsel } \\
\text { Kodlar }\end{array}$ & $\begin{array}{l}\text { Toplumsal } \\
\text { Sınıflar }\end{array}$ & $\begin{array}{l}\text { Sosyoekonomik } \\
\text { Katmanlar }\end{array}$ & $\begin{array}{l}\text { Otomobil } \\
\text { Değer } \\
\text { Aralığı } \\
\text { (TL) }\end{array}$ & $\begin{array}{l}\text { Ortaç } \\
\text { Sayısı }\end{array}$ & $\begin{array}{l}\text { Toplam } \\
\text { Sözcük } \\
\text { Sayısı }\end{array}$ & $\begin{array}{l}\text { Ortaçların } \\
\text { Toplam } \\
\text { Sözcük } \\
\text { Sayısına } \\
\text { Oranı }\end{array}$ & $\begin{array}{l}\text { Toplama } \\
\text { Göre } \\
\text { Ortaç } \\
\text { Oranı }\end{array}$ \\
\hline \multirow{3}{*}{$\begin{array}{l}\text { Dar } \\
\text { Kod }\end{array}$} & \multirow{2}{*}{ Alt Sınıf } & En Alt Katman & $0-19.999$ & 25 & 716 & $8_{3,49}$ & $\$_{15}, 8_{3}$ \\
\hline & & Alt Katman & $\begin{array}{l}20.000- \\
49.999\end{array}$ & 44 & 1221 & $\$_{3}, 60$ & 816,33 \\
\hline & & Orta Alt Katman & $\begin{array}{l}50.000- \\
99.999\end{array}$ & 44 & 1086 & 84,05 & 818,37 \\
\hline \multirow{3}{*}{$\begin{array}{l}\text { Geniș } \\
\text { Kod }\end{array}$} & & Orta Katman & $\begin{array}{l}100.000- \\
249.999\end{array}$ & 70 & 1574 & 84,45 & $\%_{20,18}$ \\
\hline & \multirow{2}{*}{ Üst Sınıf } & Üst Katman & $\begin{array}{l}250.000- \\
499.999\end{array}$ & 48 & 1255 & 83,82 & $8,17,32$ \\
\hline & & En Üst Katman & $\begin{array}{l}500.000 \\
\text { ve üzeri }\end{array}$ & 32 & 1211 & $8_{2,64}$ & 811,97 \\
\hline \multicolumn{4}{|c|}{ Genel Toplam } & 263 & 7063 & 83,72 & $\$ 100$ \\
\hline
\end{tabular}

\section{Tablo 10. Ortaç Sayıları, Dağılımları ve Oranları}

Tablo 10'da örneklemi oluşturan metinlerdeki katman, sınıf ve kodlara göre ortaç sayıları ve bunların toplam ortaç sayılarına göre oranları gösterilmiştir. En düşük ortaç oranı en alt katmanda iken en yüksek ortaç oranı orta katmandadır. En alt katmandan orta katmana doğru ortaç sayısı ve oranı artarken orta katmandan sonra bu sayı ve oran düşüşe geçmiştir. Ortaç kullanım oranlarının alt sınıftan $(\% 32,16)$ orta sınıfa $(\% 38,55)$ geçişte yükseldiği, orta sınıftan üst sınıfa $(29,29)$ geçişte ise düştüğü tespit edilmiştir. Oransal toplamlara bakıldığında ise geniş kodda \%49,47; dar kodda \%50,53'lük bir oran vardır. Dar kod ve geniş kod arasında ortaç kullanımı bakımından anlamlı bir fark görülmemektedir. 


\subsubsection{Ulaç Kullanımı}

\begin{tabular}{|c|c|c|c|c|c|c|c|}
\hline $\begin{array}{l}\text { Dilsel } \\
\text { Kodlar }\end{array}$ & $\begin{array}{l}\text { Toplumsal } \\
\text { Sınıflar }\end{array}$ & $\begin{array}{l}\text { Sosyoekonomik } \\
\text { Katmanlar }\end{array}$ & $\begin{array}{l}\text { Otomobil } \\
\text { Değer } \\
\text { Aralığı } \\
(\mathrm{TL})\end{array}$ & $\begin{array}{l}\text { Ulaç } \\
\text { Sayısı }\end{array}$ & $\begin{array}{l}\text { Toplam } \\
\text { Sözcük } \\
\text { Sayısı }\end{array}$ & $\begin{array}{l}\text { Ulaçların } \\
\text { Toplam } \\
\text { Sözcük } \\
\text { Sayısına } \\
\text { Oranı }\end{array}$ & $\begin{array}{l}\text { Toplama } \\
\text { Göre } \\
\text { Ulaç } \\
\text { Oranı }\end{array}$ \\
\hline \multirow{3}{*}{$\begin{array}{l}\text { Dar } \\
\text { Kod }\end{array}$} & \multirow[b]{2}{*}{ Alt Sinif } & En Alt Katman & $0-19.999$ & 7 & 716 & \%o, 98 & $\$ 10,02$ \\
\hline & & Alt Katman & $\begin{array}{l}20.000- \\
49.999\end{array}$ & 20 & 1221 & 81,64 & $\% 16,78$ \\
\hline & \multirow{2}{*}{ Orta Sınıf } & Orta Alt Katman & $\begin{array}{l}50.000- \\
99.999\end{array}$ & 19 & 1086 & $\mathscr{x}_{1,75}$ & 817,91 \\
\hline \multirow{3}{*}{$\begin{array}{l}\text { Geniș } \\
\text { Kod }\end{array}$} & & Orta Katman & $\begin{array}{l}100.000- \\
249.999\end{array}$ & 25 & 1574 & $\$ 1,59$ & 816,28 \\
\hline & \multirow{2}{*}{ Üst Sınıf } & Üst Katman & $\begin{array}{l}250.000- \\
499.999\end{array}$ & 25 & 1255 & 81,99 & $\$ 20,38$ \\
\hline & & En Üst Katman & $\begin{array}{l}500.000 \\
\text { ve üzeri }\end{array}$ & 22 & 1211 & $\$ 1,82$ & $\$ 18,63$ \\
\hline \multicolumn{4}{|c|}{ Genel Toplam } & 118 & 7063 & $\$ 1,63$ & $\$ 100$ \\
\hline
\end{tabular}

\section{Tablo 11. Ulaç Sayıları, Dağılımları ve Oranları}

Tablo 11'de örneklemi oluşturan metinlerdeki katman, sınıf ve kodlara göre ulaç sayıları ve bunların toplam ulaç sayılarına göre oranları gösterilmiştir. Buna göre en düşük ulaç oranı en alt katmanda iken en yüksek ulaç oranı üst katmandadır. Alt sınıfta $(\% 26,8)$, orta sınıfta $(\% 34,19)$ ve üst sınıfta $(39,01)$ ulaç kullanım oranlarının üst sınıflara doğru yükseliş eğilimi gösterdiği tespit edilmiştir. Ulaç kullanımında oransal toplamlara bakıldığında ise geniş kodda \%55,29; dar kodda \%44,71'lik bir oran vardır. Geniş kod ve dar kod arasında ulaç kullanımı bakımından fark olduğu, geniş kodda daha sık ulaç kullanılıyorken dar kodda nispeten daha seyrek ulaç kullanımının görüldüğü söylenebilir. 
4.1.8.3. Ad-eylem Kullanımı

\begin{tabular}{|c|c|c|c|c|c|c|c|}
\hline $\begin{array}{l}\text { Dilsel } \\
\text { Kodlar }\end{array}$ & $\begin{array}{l}\text { Toplumsal } \\
\text { Sınıflar }\end{array}$ & $\begin{array}{l}\text { Sosyoekonomik } \\
\text { Katmanlar }\end{array}$ & $\begin{array}{l}\text { Otomobil } \\
\text { Değer } \\
\text { Aralığı } \\
(\mathrm{TL})\end{array}$ & $\begin{array}{l}\text { Adeylem } \\
\text { Sayısı }\end{array}$ & $\begin{array}{l}\text { Toplam } \\
\text { Sözcük } \\
\text { Sayısı }\end{array}$ & $\begin{array}{l}\text { Adeylemlerin } \\
\text { Toplam } \\
\text { Sözcük } \\
\text { Sayısına } \\
\text { Oranı }\end{array}$ & $\begin{array}{l}\text { Toplama } \\
\text { Göre } \\
\text { Adeylem } \\
\text { Oranı }\end{array}$ \\
\hline \multirow{3}{*}{$\begin{array}{l}\text { Dar } \\
\text { Kod }\end{array}$} & \multirow[b]{2}{*}{ Alt Sinıf } & En Alt Katman & $0-19.999$ & 16 & 716 & $\$ 2,23$ & $\$_{16,8}$ \\
\hline & & Alt Katman & $\begin{array}{l}20.000- \\
49.999\end{array}$ & 25 & 1221 & 82,05 & 815,47 \\
\hline & \multirow{2}{*}{ Orta Sınıf } & Orta Alt Katman & $\begin{array}{l}50.000- \\
99.999\end{array}$ & 16 & 1086 & $x_{1,47}$ & $\% 11,07$ \\
\hline \multirow{3}{*}{$\begin{array}{l}\text { Geniș } \\
\text { Kod }\end{array}$} & & Orta Katman & $\begin{array}{l}100.000- \\
249.999\end{array}$ & 33 & 1574 & 82,10 & $\$_{15}, 82$ \\
\hline & \multirow{2}{*}{ Üst Sınıf } & Üst Katman & $\begin{array}{l}250.000- \\
499.999\end{array}$ & 35 & 1255 & 82,79 & $\$ 21$ \\
\hline & & En Üst Katman & $\begin{array}{l}500.000 \\
\text { ve üzeri }\end{array}$ & 32 & 1211 & $\% 2,64$ & $\% 19,88$ \\
\hline \multicolumn{4}{|c|}{ Genel Toplam } & 157 & 7063 & $\mathscr{Z}_{2,21}$ & $\$ 2100$ \\
\hline
\end{tabular}

\section{Tablo 12. Ad-eylem Sayıları, Dağılımları ve Oranları}

Tablo 12'de örneklemi oluşturan metinlerdeki katman, sınıf ve kodlara göre ad-eylem sayıları ve bunların toplam ad-eylem sayılarına göre oranları gösterilmiştir. Buna göre en düşük ad-eylem oranı orta alt katmanda iken en yüksek ad-eylem oranı en üst katmandadır. Ad-eylem kullanım oranlarının alt sınıftan $(\% 32,27)$ orta sınıfa $(\% 26,89)$ geçişte nispeten düştüğü ancak orta sınıftan üst sınıfa $(40,88)$ geçişte belirgin bir yükseliş gösterdiği tespit edilmiştir. Adeylem kullanımında oransal toplamlara bakıldığında geniş kodda \%56,70; dar kodda \%43,34'lük bir oran vardır. Geniş kod ve dar kod arasında ad-eylem kullanımı bakımından fark olduğu, geniş kodda daha sık ad-eylem kullanılıyorken dar kodda nispeten daha seyrek ad-eylem kullanımının görüldüğü söylenebilir.

\subsection{Söz Varlığıyla İlgili Özellikler}

Katmanlar, sınıflar ve kodlar arasındaki dil kullanım farklılıklarının belirlenmesinde kullanılan bir başka ölçüt de söz varlığıdır. Bu çalışmada Veith'in (2005) ortaya koyduğu söz varlığıyla ilgili özelliklerden sözcük çeșitliliği, önadlar, belirteçlere ve söz diziminde ele aldığı ilgeçlere yer verilmiş; bunlara ek olarak bağlaçlar, adıllar ve ünlemler de değerlendirme kapsamına alınmıştır. Sosyoekonomik katmanlarda görülen söz varlığı ile ilgili özellikler şunlardır: 


\subsubsection{Sözcük Sayısı}

\begin{tabular}{|c|c|c|c|c|c|c|}
\hline $\begin{array}{l}\text { Dilsel } \\
\text { Kodlar }\end{array}$ & $\begin{array}{l}\text { Toplumsal } \\
\text { Sınıflar }\end{array}$ & $\begin{array}{l}\text { Sosyoekonomik } \\
\text { Katmanlar }\end{array}$ & $\begin{array}{l}\text { Otomobil Değer } \\
\text { Aralığı (TL) }\end{array}$ & $\begin{array}{l}\text { Toplam } \\
\text { Sözcük } \\
\text { Sayısı }\end{array}$ & $\begin{array}{l}\text { Toplama } \\
\text { Göre Sözcük } \\
\text { Oranı }\end{array}$ & $\begin{array}{l}\text { Ilan } \\
\text { Sayısı }\end{array}$ \\
\hline \multirow{3}{*}{$\begin{array}{l}\text { Dar } \\
\text { Kod }\end{array}$} & \multirow{2}{*}{ Alt Sınıf } & En Alt Katman & $0-19.999$ & 716 & $\$ 10,13$ & 25 \\
\hline & & Alt Katman & $20.000-49 \cdot 999$ & 1221 & $\$ 17,29$ & 25 \\
\hline & \multirow{2}{*}{ Orta Sınıf } & Orta Alt Katman & $50.000-99.999$ & 1086 & $\$ 15,38$ & 25 \\
\hline \multirow{3}{*}{$\begin{array}{l}\text { Geniș } \\
\text { Kod }\end{array}$} & & Orta Katman & $100.000-249 \cdot 999$ & 1574 & $\$_{22,29}$ & 25 \\
\hline & \multirow{2}{*}{ Üst Sınıf } & Üst Katman & $250.000-499.999$ & 1255 & $\$ 17,77$ & 25 \\
\hline & & En Üst Katman & 500.000 ve üzeri & 1211 & $\$ 17,14$ & 25 \\
\hline \multicolumn{4}{|c|}{ Genel Toplam } & 7063 & 8100 & 150 \\
\hline
\end{tabular}

Tablo 13. Sözcük Sayıları, Dağılımları ve Oranları

Söz varlığı ile ilgili genel bir değerlendirme yapabilmek amacıyla öncelikli olarak metinlerde yer alan sözcük sayıları belirlenmiştir. Tablo 13'te örneklemi oluşturan metinlerdeki katman, sınıf ve kodlara göre sözcük sayıları ve bunların genel toplama göre oranları gösterilmiștir. Görüldüğü gibi en yüksek sözcük sayısı orta katmanda, en düşük sözcük sayısı ise en alt katmandadır. Oransal olarak bakıldığında en düşük sözcük sayısı oranı en alt katmanda iken en yüksek sözcük sayısı oranı orta katmandadır. Sözcük oranı alt sınıfta çok düşükken, üst sınıfta nispeten yüksek, orta sınıfta ise en yüksektir. Oransal olarak dar kodun sözcük sayısı oranı toplamı \%42,8 iken geniş kodun sözcük sayısı oranı toplamı \%57,2'dir. Bu noktada geniş koddaki sözcük sayısının dar koda göre fazla olduğu görülmektedir. 
4.2.2. Sözcük Çeşitliliği

\begin{tabular}{|c|c|c|c|c|c|c|c|}
\hline $\begin{array}{l}\text { Dilsel } \\
\text { Kodlar }\end{array}$ & $\begin{array}{l}\text { Toplumsal } \\
\text { Sınıflar }\end{array}$ & $\begin{array}{l}\text { Sosyoekonomik } \\
\text { Katmanlar }\end{array}$ & $\begin{array}{l}\text { Otomobil } \\
\text { Değer } \\
\text { Aralığı } \\
(\mathrm{TL})\end{array}$ & $\begin{array}{l}\text { Benzersiz } \\
\text { Madde } \\
\text { Bașı } \\
\text { Sayısı }\end{array}$ & $\begin{array}{l}\text { Toplam } \\
\text { Sözcük } \\
\text { Sayısı }\end{array}$ & $\begin{array}{l}\text { Benzersiz } \\
\text { Madde } \\
\text { Bașlarının } \\
\text { Toplam } \\
\text { Sözcük } \\
\text { Sayısına } \\
\text { Oranı }\end{array}$ & $\begin{array}{l}\text { Toplama } \\
\text { Göre } \\
\text { Benzersiz } \\
\text { Madde } \\
\text { Bașı } \\
\text { Oranı }\end{array}$ \\
\hline \multirow{3}{*}{$\begin{array}{l}\text { Dar } \\
\text { Kod }\end{array}$} & \multirow{2}{*}{ Alt Sinıf } & En Alt Katman & $\begin{array}{l}0- \\
19.999\end{array}$ & 295 & 716 & 841,2 & $\$ 17,49$ \\
\hline & & Alt Katman & $\begin{array}{l}20.000- \\
49.999\end{array}$ & 446 & 1221 & $\% 36,53$ & 815,51 \\
\hline & \multirow{2}{*}{ Orta Sınıf } & Orta Alt Katman & $\begin{array}{l}50.000- \\
99.999\end{array}$ & 466 & 1086 & 842,9 & $\$ 18,22$ \\
\hline \multirow{3}{*}{$\begin{array}{l}\text { Geniș } \\
\text { Kod }\end{array}$} & & Orta Katman & $\begin{array}{l}100.000- \\
249.999\end{array}$ & 613 & 1574 & $8_{38,95}$ & $\$ 16,54$ \\
\hline & \multirow{2}{*}{ Üst Sınıf } & Üst Katman & $\begin{array}{l}250.000- \\
499.999\end{array}$ & 479 & 1255 & $\% 38,17$ & $\$ 16,21$ \\
\hline & & En Üst Katman & $\begin{array}{l}500.000 \\
\text { ve üzeri }\end{array}$ & 452 & 1211 & $\%_{37,74}$ & $\$ 16,03$ \\
\hline \multicolumn{4}{|c|}{ Genel Toplam } & 2751 & 7063 & $8_{38,95}$ & $\$_{100}$ \\
\hline
\end{tabular}

\section{Tablo 14. Sözcük çeșitliliği}

Tablo 14'te örneklemi oluşturan metinlerdeki katman, sınıf ve kodlara göre sözcük çeşitliliğini gösteren benzersiz madde başı sayıları ve bunların toplama göre oranları gösterilmiştir. En yüksek benzersiz madde başı sayısı orta katmanda, en düşük benzersiz madde başı sayısı en alt katmanda; en yüksek benzersiz madde başı oranı orta alt katmanda, en düşük benzersiz madde başı oranı ise üst katmandadır. Alt sınıfta (\%33), orta sınıfta $(\% 34,76)$ ve üst sınıfta $(32,24)$ benzersiz madde başı oranları birbirine çok yakındır. Dar kodda \%51,22 oranında benzersiz madde başı bulunmaktayken geniş kodda ise bu oranın \%48,78'e düştüğü görülmüştür. Bu bakımdan bu tabloda değerlendirilen verilerden elde edilen bulguların Bernstein (1959: 312) ve Veith'in (2005: 103) ifadeleri ile nispeten çeliştiği, dar koddaki sözcük çeșitliliğinin geniş koda oranla daha fazla olduğu sonucuna ulaşılmıştır. Derlem çalışmalarında derlemi oluşturan sözcük sayısı arttıkça sözcük çeşitliliğinin azalacağı öngörülmektedir. Örneğin 1000 sözcükten oluşan bir metinde sözcük çeşitliliği \%40’larda iken daha az sözcükten oluşan bir metinde \%70'lere çıkabilir; 4 milyon sözcükten oluşan bir derlemde ise sözcük çeşitliliğinin \%2'lere düşmesi mümkündür (Lexically, 2021). Buna göre dar kodda bulunan sözcük çeşitliliğinin yüksek görünmesi bu koddaki sözcük sayısının düşüklüğü ile açıklanabilir. Bu çalışmada metinler sözcük sayısına bakılarak değil ilan sayısına göre seçilmiştir. Sözcük sayısı bakımından dengeli bir derlem kullanılarak yapılacak bir karşılaştırmada sözcük çeşitliliği bakımından Bernstein'ı (1959) ve Veith’i (2005) destekleyici sonuçların elde edileceği tahmin edilmektedir. 


\subsection{3. Önad Kullanımı}

\begin{tabular}{|c|c|c|c|c|c|c|c|}
\hline $\begin{array}{l}\text { Dilsel } \\
\text { Kodlar }\end{array}$ & $\begin{array}{l}\text { Toplumsal } \\
\text { Sinıflar }\end{array}$ & $\begin{array}{l}\text { Sosyoekonomik } \\
\text { Katmanlar }\end{array}$ & $\begin{array}{l}\text { Otomobil } \\
\text { Değer } \\
\text { Aralığı } \\
(\mathrm{TL})\end{array}$ & $\begin{array}{l}\text { Önad } \\
\text { Sayısı }\end{array}$ & $\begin{array}{l}\text { Toplam } \\
\text { Sözcük } \\
\text { Sayısı }\end{array}$ & $\begin{array}{l}\text { Önadların } \\
\text { Toplam } \\
\text { Sözcük } \\
\text { Sayısına } \\
\text { Oranı }\end{array}$ & $\begin{array}{l}\text { Toplama } \\
\text { Göre } \\
\text { Önad } \\
\text { Oranı }\end{array}$ \\
\hline \multirow{3}{*}{$\begin{array}{l}\text { Dar } \\
\text { Kod }\end{array}$} & \multirow[b]{2}{*}{ Alt Sinıf } & En Alt Katman & 0.19 .999 & 100 & 716 & $\$_{13}, 97$ & $\$ 15,21$ \\
\hline & & Alt Katman & $\begin{array}{l}20.000- \\
49.999\end{array}$ & 197 & 1221 & 816,13 & $\$ 17,56$ \\
\hline & \multirow{2}{*}{ Orta Sınıf } & Orta Alt Katman & $\begin{array}{l}50.000- \\
99.999\end{array}$ & 167 & 1086 & $\$ 15,38$ & $\$_{16,74}$ \\
\hline \multirow{3}{*}{$\begin{array}{l}\text { Geniș } \\
\text { Kod }\end{array}$} & & Orta Katman & $\begin{array}{l}100.000- \\
249.999\end{array}$ & 241 & 1574 & 815,31 & 816,67 \\
\hline & \multirow{2}{*}{ Üst Sınıf } & Üst Katman & $\begin{array}{l}250.000- \\
499.999\end{array}$ & 198 & 1255 & $\$ 15,78$ & $\$ 17,18$ \\
\hline & & En Üst Katman & $\begin{array}{l}500.000 \\
\text { ve üzeri }\end{array}$ & 185 & 1211 & $\$_{15,28}$ & $\$_{16,64}$ \\
\hline \multicolumn{4}{|c|}{ Genel Toplam } & 1088 & 7063 & 815,3 & $\$ 100$ \\
\hline
\end{tabular}

Tablo 15. Önad Sayıları, Dağılımları ve Oranları

Tablo 15'te örneklemi oluşturan metinlerdeki katman, sınıf ve kodlara göre önad sayıları ve bunların toplam önad sayılarına göre oranları gösterilmiştir. En düşük önad sayısı ve oranı en alt katmanda; en yüksek önad sayısı orta katmanda, en yüksek önad oranı ise alt katmandadır. Alt sınıfta $(\% 32,77)$, orta sınıfta $(\% 33,41)$ ve üst sınıfta $(33,82)$ önad kullanım oranlarının birbirine çok yakın olduğu görülmüștür. Kodlara göre önad kullanım oranlarına bakıldığında da geniş kodda \%50,49; dar kodda \%49,51'lik bir oran ortaya çıkmaktadır. Dar kod ve geniş kod arasında önad kullanımı bakımından anlamlı bir fark görülmemektedir.

Önad sayı ve oranlarının katmanlara göre dağıımı şöyledir:

En alt katman: 100 içerisinden 61 farklı önad \%61

Alt katman: 197 içerisinden 93 farklı önad \%47,21

Orta alt katman: 167 içerisinden 92 farklı önad \%55,09

Orta katman: 241 içerisinden 117 farklı önad \%48,55

Üst katman: 198 içerisinden 101 farklı önad \%51,01

En üst katman: 185 içerisinden 86 farklı önad \%46,49 


\subsubsection{Belirteç Kullanımı}

\begin{tabular}{|c|c|c|c|c|c|c|c|}
\hline $\begin{array}{l}\text { Dilsel } \\
\text { Kodlar }\end{array}$ & $\begin{array}{l}\text { Toplumsal } \\
\text { Sınıflar }\end{array}$ & $\begin{array}{l}\text { Sosyoekonomik } \\
\text { Katmanlar }\end{array}$ & $\begin{array}{l}\text { Otomobil } \\
\text { Değer } \\
\text { Aralığı } \\
\text { (TL) }\end{array}$ & $\begin{array}{l}\text { Belirteç } \\
\text { Sayısı }\end{array}$ & $\begin{array}{l}\text { Toplam } \\
\text { Sözcük } \\
\text { Sayısı }\end{array}$ & $\begin{array}{l}\text { Belirteçlerin } \\
\text { Toplam } \\
\text { Sözcük } \\
\text { Sayısına } \\
\text { Oranı }\end{array}$ & $\begin{array}{l}\text { Toplama } \\
\text { Göre } \\
\text { Belirteç } \\
\text { Oranı }\end{array}$ \\
\hline \multirow{3}{*}{$\begin{array}{l}\text { Dar } \\
\text { Kod }\end{array}$} & \multirow[b]{2}{*}{ Alt Sinıf } & En Alt Katman & 0.19 .999 & 34 & 716 & 84,75 & $\$ 19,07$ \\
\hline & & Alt Katman & $\begin{array}{l}20.000- \\
49.999\end{array}$ & 54 & 1221 & 94,42 & $\% 17,74$ \\
\hline & Orta Sınıf & Orta Alt Katman & $\begin{array}{l}50.000- \\
99.999\end{array}$ & 46 & 1086 & 94,24 & $\$ 17,02$ \\
\hline \multirow{3}{*}{$\begin{array}{l}\text { Geniș } \\
\text { Kod }\end{array}$} & & Orta Katman & $\begin{array}{l}100.000- \\
249.999\end{array}$ & 60 & 1574 & $\$_{3,81}$ & 815,3 \\
\hline & \multirow{2}{*}{ Üst Sınıf } & Üst Katman & $\begin{array}{l}250.000- \\
499.999\end{array}$ & 52 & 1255 & 94,14 & $\$ 16,62$ \\
\hline & & En Üst Katman & $\begin{array}{l}500.000 \\
\text { ve üzeri }\end{array}$ & 43 & 1211 & 83,55 & 814,25 \\
\hline \multicolumn{4}{|c|}{ Genel Toplam } & 289 & 7063 & $\$ 4,09$ & $\$ 100$ \\
\hline
\end{tabular}

Tablo 16. Belirteç Sayıları, Dağılımları ve Oranları

Tablo 16'da örneklemi oluşturan metinlerdeki katman, sınıf ve kodlara göre belirteç sayıları ve bunların toplam belirteç sayılarına göre oranları gösterilmiştir. Buna göre toplama göre belirteç oranı en yüksek en alt katmanda, en düşük en üst katmanda kullanılmaktadır. Alt sınıfta $(\% 36,81)$, orta sınıfta $(\% 32,32)$ ve üst sınıfta $(30,87)$ belirteç kullanım oranlarının üst sınıflara doğru düșüş eğilimi gösterdiği tespit edilmiştir. Kodların oransal toplamına bakıldığında belirteç kullanımında geniş kodda \%46,17; dar kodda \%53,82'lik bir oran ortaya çıkmaktadır. Bu bulguların Veith'in (2005) ortaya koyduğu ölçütlerle nispeten çeliştiği söylenebilir.

Belirteç sayı ve oranlarının katmanlara göre dağılımı şöyledir:

En alt katman: 34 içerisinden 26 farklı belirteç \%76,47

Alt katman: 54 içerisinden 25 farklı belirteç \%46,3

Orta alt katman: 46 içerisinden 23 farklı belirteç \%50

Orta katman: 60 içerisinden 31 farklı belirteç \%51,67

Üst katman: 52 içerisinden 31 farklı belirteç \%59,62

En üst katman: 43 içerisinden 23 farklı belirteç \%53,49 


\subsection{5. ilgeç Kullanımı}

\begin{tabular}{|c|c|c|c|c|c|c|c|}
\hline $\begin{array}{l}\text { Dilsel } \\
\text { Kodlar }\end{array}$ & $\begin{array}{l}\text { Toplumsal } \\
\text { Sınıflar }\end{array}$ & $\begin{array}{l}\text { Sosyoekonomik } \\
\text { Katmanlar }\end{array}$ & $\begin{array}{l}\text { Otomobil } \\
\text { Değer } \\
\text { Aralığı } \\
(\mathrm{TL})\end{array}$ & $\begin{array}{l}\text { İlgeç } \\
\text { Sayısı }\end{array}$ & $\begin{array}{l}\text { Toplam } \\
\text { Sözcük } \\
\text { Sayısı }\end{array}$ & $\begin{array}{l}\text { İlgeçlerin } \\
\text { Toplam } \\
\text { Sözcük } \\
\text { Sayısına } \\
\text { Oranı }\end{array}$ & $\begin{array}{l}\text { Toplama } \\
\text { Göre } \\
\text { İlgeç } \\
\text { Oranı }\end{array}$ \\
\hline \multirow{3}{*}{$\begin{array}{l}\text { Dar } \\
\text { Kod }\end{array}$} & \multirow[b]{2}{*}{ Alt Sinıf } & En Alt Katman & 0.19 .999 & 13 & 716 & 81,81 & 816,03 \\
\hline & & Alt Katman & $\begin{array}{l}20.000- \\
49.999\end{array}$ & 28 & 1221 & 82,29 & $q_{20,28}$ \\
\hline & Ort & Orta Alt Katman & $\begin{array}{l}50.000- \\
99.999\end{array}$ & 18 & 1086 & $\$_{1}, 65$ & $\$ 14,61$ \\
\hline \multirow{3}{*}{$\begin{array}{l}\text { Geniș } \\
\text { Kod }\end{array}$} & & Orta Katman & $\begin{array}{l}100.000- \\
249.999\end{array}$ & 40 & 1574 & $.82,54$ & $\$ 22,5$ \\
\hline & \multirow{2}{*}{ Üst Sınıf } & Üst Katman & $\begin{array}{l}250.000- \\
499.999\end{array}$ & 17 & 1255 & 81,35 & 811,96 \\
\hline & & En Üst Katman & $\begin{array}{l}500.000 \\
\text { ve ūzeri }\end{array}$ & 20 & 1211 & 81,65 & 814,62 \\
\hline \multicolumn{4}{|c|}{ Genel Toplam } & 136 & 7063 & 81,92 & $\$ 100$ \\
\hline
\end{tabular}

\section{Tablo 17. Illgeç Sayıları, Dağılımları ve Oranları}

Tablo 17'de örneklemi oluşturan metinlerde katmanlara göre ilgeç sayıları ve oranları gösterilmiştir. Buna göre en yüksek ilgeç sayısı ve oranı orta katmanda; en düşük ilgeç sayısı üst katmanda, en düşük ilgeç oranı ise üst katmandadır. ilgeçler genellikle ad türünden bir sözcükle öbek kurdukları için tümce uzunluğunu artırmaktadır. Kodların oransal toplamına bakıldığında ilgeç kullanımında geniş kodda \%49,08; dar kodda \%50,92'lik bir oran ortaya çıkmaktadır. Bu noktada ilgeç kullanım çeşitliliği de incelenmiştir. Katmanlara göre ilgeç çeşitliliği şöyledir:

En alt katmandaki toplam ilgeç sayısı 13'tür ve bu katmanda 4 farklı ilgeç kullanılmıştır. En alt katmandaki ilgeçler ve sıklık sayıları şunlardır: kadar (6), gibi (3), göre (2), için (2).

Alt katmandaki toplam ilgeç sayısı 28'dir ve bu katmanda 6 farklı ilgeç kullanılmıştır. Alt katmandaki ilgeçler ve sıklık sayıları: dolayı (4), için (10), kadar (5), gibi (4), hakkında (1), ile (3).

Orta alt katmandaki toplam ilgeç sayısı 18'dir ve bu katmanda 5 farklı kullanılmıştır. Orta alt katmandaki ilgeçler ve sıklık sayıları: beri (1), için (4), dolayı (3), ile (7), kadar (3). 
Orta katmandaki toplam ilgeç sayısı 40'tır ve bu katmanda 8 farklı ilgeç kullanılmıştır. Orta katmandaki ilgeçler ve sıklık sayıları: ile (13), dolayı (6), hakkında (1), için (5), gibi (6), bile (2), kadar (6), beri (1).

Üst katmandaki toplam ilgeç sayısı 17'dir ve bu katmanda 6 farklı ilgeç kullanılmıştır. Üst katmandaki ilgeçler ve sıklık sayıları: dolayı (2), gibi (3), kadar (4), için (5), ile (2), beri (1).

En üst katmandaki toplam ilgeç sayısı 20'dir ve 7 farklı ilgeç kullanılmıştır. En üst katmandaki ilgeçler ve sıklık sayıları: kadar (3), ile (5), için (5), dolayı (3), beri (2), karşı (1), gibi (1).

Ilgeç çeşitliliği açısından yapılan değerlendirme sonucu en az ilgeç çeşitliliğinin en alt katmanda, en çok ilgeç çeşitliliğinin orta katmanda görüldüğü tespit edilmiştir. Her ne kadar ilgeç kullanım oranları kodlar arasında birbirine yakın görünse de ilgeç çeşitliliğinin geniş kodda dar koda göre daha fazla olduğu saptanmıştır. Bu bulguların Bernstein'ın (1959: 312) kurallı dil için ifade ettiği "mantıksal ilişkileri gösteren ilgeçlerin sıkça kullanılmasının yanı sıra zamansal ve uzamsal yakınlığı gösteren ilgeçlerin sık kullanılması” tespitiyle örtüştüğü söylenebilir.

\subsubsection{Bağlaç Kullanımı}

\begin{tabular}{|c|c|c|c|c|c|c|c|}
\hline $\begin{array}{l}\text { Dilsel } \\
\text { Kodlar }\end{array}$ & $\begin{array}{l}\text { Toplumsal } \\
\text { Sınıflar }\end{array}$ & $\begin{array}{l}\text { Sosyoekonomik } \\
\text { Katmanlar }\end{array}$ & $\begin{array}{l}\text { Otomobil } \\
\text { Değer } \\
\text { Aralığı } \\
\text { (TL) }\end{array}$ & $\begin{array}{l}\text { Bağlaç } \\
\text { Sayısı }\end{array}$ & $\begin{array}{l}\text { Toplam } \\
\text { Sözcük } \\
\text { Sayısı }\end{array}$ & $\begin{array}{l}\text { Bağlaçların } \\
\text { Toplam } \\
\text { Sözcük } \\
\text { Sayısına } \\
\text { Oranı }\end{array}$ & $\begin{array}{l}\text { Toplama } \\
\text { Göre } \\
\text { Bağlaç } \\
\text { Oranı }\end{array}$ \\
\hline \multirow{3}{*}{$\begin{array}{l}\text { Dar } \\
\text { Kod }\end{array}$} & \multirow[b]{2}{*}{ Alt Sinıf } & En Alt Katman & $0-19.999$ & 16 & 716 & 82,23 & 814,84 \\
\hline & & Alt Katman & $\begin{array}{l}20.000- \\
49.999\end{array}$ & 34 & 1221 & 82,78 & 818,5 \\
\hline & Orta Sınıf & Orta Alt Katman & $\begin{array}{l}50.000- \\
99.999\end{array}$ & 18 & 1086 & $\$ 1,66$ & $\$ 11,04$ \\
\hline \multirow{3}{*}{$\begin{array}{l}\text { Geniș } \\
\text { Kod }\end{array}$} & & Orta Katman & $\begin{array}{l}100.000- \\
249.999\end{array}$ & 32 & 1574 & 82,03 & 813,51 \\
\hline & \multirow{2}{*}{ Üst Sınıf } & Üst Katman & $\begin{array}{l}250.000- \\
499.999\end{array}$ & $3^{8}$ & 1255 & 83,03 & $\% 20,16$ \\
\hline & & En Üst Katman & $\begin{array}{l}500.000 \\
\text { ve üzeri }\end{array}$ & 40 & 1211 & 83,3 & 821,96 \\
\hline \multicolumn{4}{|c|}{ Genel Toplam } & 178 & 7063 & 82,52 & $\% 100$ \\
\hline
\end{tabular}

Tablo 18. Bağlaç Sayıları, Dağılımları ve Oranları

Tablo 18'de, örneklemi oluşturan metinlerdeki katman, sınıf ve kodlara göre bağlaç sayıları ve bunların toplam bağlaç sayılarına göre oranları 
gösterilmiştir. Buna göre en yüksek bağlaç sayısı ve oranı en üst katmanda; en düşük bağlaç sayısı en alt katmanda, en düşük bağlaç oranı ise orta alt katmanda görülmektedir. Bağlaç kullanımında katmanlar arasında alt katmanlardan üst katmanlara doğru bir yükseliş olduğu görülmektedir. Kodların oransal toplamına bakıldığında bağlaç kullanımında geniş kodda \%55,63; dar kodda \%44,38'lik bir oran ortaya çıkmaktadır. En belirgin fark ise üst sınıftaki bağlaç kullanımının alt ve orta sınıfa göre çok daha fazla olmasıdır. Bağlaçların \%42,12'si üst sınıfta görülmekteyken \%33,34'ü alt, \%24,55'i orta sınıfta yer almaktadır. Bernstein'ın (1959: 311-312) kamu dili için kullandığı "az sayıdaki bağlaçların yinelenerek kullanımı" ifadesini alt ve orta sınıflar ile dar koddaki; kuralı dil için kullandığı "mantıksal değişiklikler ve vurgulamalar; dilbilgisel açıdan karmaşık tümce yapılarıyla, özellikle yan tümcelerle ve çeşitli bağlaçlarla sağlanmaktadır." ifadesini de üst sınıf ve geniş koddaki bağlaç kullanımı bulguları desteklemektedir.

Bağlaç kullanımındaki çeşitlilik de kodlar arasındaki farklılı̆ı göstermesi bakımından önemli bir ölçüttür. En alt katmanda 6, alt katmanda 7, orta alt katmanda 4, orta katmanda 5, üst ve en üst katmanda 6 farklı bağlaç kullanıldığı tespit edilmiştir. Dar koddaki bağlaç çeşitliliği 5,67 iken geniş kodda görülen oran da aynıdır. Çeşitlilik açısından yapılan değerlendirmede dar ve geniş kod arasında bir farklılık olmadığı görülmüştür.

Katmanlara göre bağlaç örnekleri ve çeşitliliği şöyledir:

En alt katmandaki toplam bağlaç sayısı 16'dır ve bu katmanda 6 farklı bağlaç kullanılmıştır. En alt katmandaki bağlaçlar ve sıklık sayıları şöyledir: ve (6), lakin (1), eğer (1), ki (2), da (5), ile (1).

Alt katmandaki toplam bağlaç sayısı 34'tür ve bu katmanda 7 farklı bağlaç kullanılmıştır. Alt katmandaki bağlaçlar ve sıkık sayıları şöyledir: ve (21), da (7), ama (2), ancak (1), fakat (1), yahut (1), veya (1).

Orta alt katmandaki toplam bağlaç sayısı 18'dir ve bu katmanda 4 farklı bağlaç kullanılmıştır. Orta alt katmandaki bağlaçlar ve sıklık sayıları şölyedir: ve (12), da (4), veya (1), ama (1).

Orta katmandaki toplam bağlaç sayısı 32'dir ve bu katmanda 5 farklı bağlaç kullanılmıştır. Orta katmandaki bağlaçlar ve sıklık sayıları şöyledir: ve (22), da (7), hem ... hem (1), veya (1), ya da (1).

Üst katmandaki toplam bağlaç sayısı 38'dir ve 6 farklı bağlaç kullanılmıştır. Üst katmandaki bağlaçlar ve sıklık sayıları şöyledir: ve (27), da (3), veya (4), dahi (1), ya da (2), ile (1).

En üst katmandaki toplam bağlaç sayısı 40'tır ve bu katmanda 6 farklı bağlaç kullanılmıştır. En üst katmandaki bağlaçlar ve sıklık sayıları şöyledir: ve (32), da (4), dahi (1), veya (1), ile (1), ama (1). 
4.2.7. Adıl Kullanımı

\begin{tabular}{|c|c|c|c|c|c|c|c|}
\hline \multirow{3}{*}{$\begin{array}{l}\text { Dilsel Kodlar } \\
\text { Toplumsal } \\
\text { Sınıflar } \\
\text { Sosyoekonomik } \\
\text { Katmanlar }\end{array}$} & \multicolumn{3}{|c|}{ Dar Kod } & \multicolumn{3}{|c|}{ Geniș Kod } & \multirow{4}{*}{$\begin{array}{l}\text { Genel } \\
\text { Toplam }\end{array}$} \\
\hline & \multicolumn{2}{|c|}{ Alt Sınıf } & \multicolumn{2}{|c|}{ Orta Sinıf } & \multicolumn{2}{|c|}{ Üst Sınıf } & \\
\hline & $\begin{array}{c}\text { En Alt } \\
\text { Katman }\end{array}$ & $\begin{array}{c}\text { Alt } \\
\text { Katman }\end{array}$ & $\begin{array}{l}\text { Orta Alt } \\
\text { Katman }\end{array}$ & $\begin{array}{l}\text { Orta } \\
\text { Katman }\end{array}$ & $\begin{array}{c}\text { Üst } \\
\text { Katman }\end{array}$ & $\begin{array}{l}\text { En Üst } \\
\text { Katman }\end{array}$ & \\
\hline $\begin{array}{l}\text { Otomobil Değer } \\
\text { Aralığı (TL) }\end{array}$ & $0-19.999$ & $\begin{array}{l}20.000- \\
49.999\end{array}$ & $\begin{array}{l}50.000- \\
99.999\end{array}$ & $\begin{array}{l}100.000- \\
249.999\end{array}$ & $\begin{array}{l}250.000- \\
499.999\end{array}$ & $\begin{array}{l}500.000 \\
\text { ve üzeri }\end{array}$ & \\
\hline Kiși Adılı Sayısı & 3 (ben) & 1 (ben) & 2 (ben) & 6 (ben) & - & - & 12 \\
\hline İșaret Adılı Sayısı & $1(0)$ & - & - & $1(0)$ & $2(\mathrm{bu}, 0)$ & 3 (bu) & 7 \\
\hline $\begin{array}{l}\text { Dönüșlülük Adılı } \\
\text { Sayısı }\end{array}$ & - & $\begin{array}{l}1 \\
\text { (kendi) }\end{array}$ & $\begin{array}{l}\mathbf{1} \\
\text { (kendi) }\end{array}$ & 2 & 1 (kendi) & - & 5 \\
\hline Soru Adılı Sayısı & $\begin{array}{l}2 \text { (kaç, } \\
\text { ne) }\end{array}$ & - & - & - & - & - & 2 \\
\hline $\begin{array}{l}\text { Karșılıklılık Adılı } \\
\text { Sayısı }\end{array}$ & - & $\begin{array}{l}1 \\
\text { (birbiri) }\end{array}$ & - & - & - & - & 1 \\
\hline $\begin{array}{l}\text { Belirsizlik Adılı } \\
\text { Sayısı }\end{array}$ & $\begin{array}{l}4 \text { [hepsi } \\
(2), \text { şey, } \\
\text { fln] }\end{array}$ & $\begin{array}{l}\mathbf{1} \\
\text { (hepsi) }\end{array}$ & $\begin{array}{l}3 \text { [hepsi } \\
(2), \text { șey] }\end{array}$ & $\begin{array}{l}6[\text { șey } \\
(5), \\
\text { hepsi] }\end{array}$ & $\begin{array}{l}6 \text { [șey } \\
(5), \\
\text { herkes] }\end{array}$ & $\begin{array}{l}6 \text { [șey } \\
(4), \text { filan, } \\
\text { hepsi] }\end{array}$ & 26 \\
\hline $\begin{array}{l}\text { Toplam Adıl } \\
\text { Sayısı }\end{array}$ & 10 & 4 & 6 & 15 & 9 & 9 & 53 \\
\hline $\begin{array}{l}\text { Toplam Sözcük } \\
\text { Sayısı }\end{array}$ & 716 & 1221 & 1086 & 1574 & 1255 & 1211 & 7063 \\
\hline $\begin{array}{l}\text { Adılların Toplam } \\
\text { Sözcük Sayısına } \\
\text { Oranı }\end{array}$ & 81,4 & \%o,33 & \%०,55 & \%०,95 & 80,72 & 80,74 & 80,75 \\
\hline $\begin{array}{l}\text { Toplama Göre } \\
\text { Adıl Oranı }\end{array}$ & 829,85 & 87,04 & 811,73 & $\$ 20,26$ & 815,35 & $\%_{15,78}$ & $\$ 100$ \\
\hline
\end{tabular}

Tablo 19. Adıl Sayıları, Dağılımları ve Oranları

Tablo 19'da örneklemi oluşturan metinlerdeki katman, sınıf ve kodlara göre, türlerine göre ve toplam adıl sayıları ile bunların toplama göre oranları gösterilmiştir. En yüksek adıl sayısı orta katmanda, en düşük adıl sayısı alt katmanda; en yüksek adıl kullanım oranı en alt katmanda, en düşük adıl kullanım oranı ise alt katmanda görülmektedir. Adıl oranı alt, orta ve üst sınıflarda birbirine çok yakındır. Geniş kodda adıl oranı ortalaması \%51,39 iken dar kodda adıl oranı ortalaması \%48,62'dir. Dar kod ve geniş kod arasındaki adıl oranı da birbirine çok yakındır.

Adıl türlerine ayrı ayrı bakıldığında katman, sınıf ve kodlar arasında farklılaşmalar olduğu dikkati çekmektedir. En çok kişi adılı sayısı orta katmanda görülmekteyken üst ve en üst katmanda kişi adılı kullanılmamıştır. Üst sınıfta kişi adılı hiç yokken orta sınıfta kişi adılı kullanım oranı en yüksektir. Dar kodda ve geniş kodda eşit sayıda kişi adılı kullanıldığı görülmektedir.

Ayrıca kodlar arasında dikkati çeken bir başka husus da belirsizlik adıllarının geniş kodda sık olarak $(\% 69,23)$ kullanılıyorken dar kodda daha seyrek $(\% 30,77)$ kullanıldığının görülmesidir. Lange'ye göre de belirsiz adılların sık kullanımı kurallı dilin, bu adılların seyrek kullanımı halka ait dilin özelliğidir 
(Aktaran Dağabakan, 2019: 48). Bu bakımdan çalışmanın bulguları bu tespiti destekler niteliktedir.

4.2.8. Ünlem Kullanımı

\begin{tabular}{|c|c|c|c|c|c|c|c|}
\hline $\begin{array}{l}\text { Dilsel } \\
\text { Kodlar }\end{array}$ & $\begin{array}{l}\text { Toplumsal } \\
\text { Sınıflar }\end{array}$ & $\begin{array}{l}\text { Sosyoekonomik } \\
\text { Katmanlar }\end{array}$ & $\begin{array}{l}\text { Otomobil } \\
\text { Değer } \\
\text { Aralığı } \\
(\mathrm{TL})\end{array}$ & $\begin{array}{l}\text { Ünlem } \\
\text { Sayısı }\end{array}$ & $\begin{array}{l}\text { Toplam } \\
\text { Sözcük } \\
\text { Sayısı }\end{array}$ & $\begin{array}{l}\text { Ünlemlerin } \\
\text { Toplam } \\
\text { Sözcük } \\
\text { Sayısına } \\
\text { Oranı }\end{array}$ & $\begin{array}{l}\text { Toplama } \\
\text { Göre } \\
\text { Ünlem } \\
\text { Oranı }\end{array}$ \\
\hline \multirow{3}{*}{$\begin{array}{l}\text { Dar } \\
\text { Kod }\end{array}$} & \multirow[b]{2}{*}{ Alt Sınıf } & En Alt Katman & $0-19.999$ & 2 & 716 & \%o,28 & $\$_{48,28}$ \\
\hline & & Alt Katman & $\begin{array}{l}20.000- \\
49.999\end{array}$ & - & 1221 & $\% 0$ & \%o \\
\hline & \multirow{2}{*}{ Orta Sınıf } & Orta Alt Katman & $\begin{array}{l}50.000- \\
99.999\end{array}$ & 1 & 1086 & $\% 0,09$ & $\$_{15,52}$ \\
\hline \multirow{3}{*}{$\begin{array}{l}\text { Geniș } \\
\text { Kod }\end{array}$} & & Orta Katman & $\begin{array}{l}100.000- \\
249.999\end{array}$ & 2 & 1574 & So,13 & $\% 22,41$ \\
\hline & \multirow{2}{*}{ Üst Sınıf } & Üst Katman & $\begin{array}{l}250.000- \\
499.999\end{array}$ & 1 & 1255 & $\% 0,08$ & 813,79 \\
\hline & & En Üst Katman & $\begin{array}{l}500.000 \\
\text { ve üzeri }\end{array}$ & - & 1211 & \%o & \%o \\
\hline \multicolumn{4}{|c|}{ Genel Toplam } & 6 & 7063 & \%०,08 & $\$ 100$ \\
\hline
\end{tabular}

Tablo 20. Ünlem Sayıları, Dağılımları ve Oranları

Konuşma diline ait metinler olmamaları, diyalog içermemeleri, daha çok betimleme tümceleri içermeleri vb. ilan dili özelliklerinden dolayı örneklemi oluşturan metinlerde çok az sayıda ünlem bulunmaktadır. Her ne kadar yeterli sayıda veri bulunmasa da Tablo 20'de örneklemi oluşturan metinlerdeki katman, sınıf ve kodlara göre ünlem sayıları ve toplam ünlem sayılarına göre oranları gösterilmiştir. En yüksek ünlem sayısı en alt ve orta katmanda, en yüksek ünlem kullanım oranı en alt katmanda görülmekteyken alt katmanda ve en üst katmanda ünlem kullanım örneği yoktur. Ünlem oranı üst sınıfta çok düşükken, orta sınıfta nispeten daha yüksek, alt sınıfta ise en yüksektir. Dar kodda ünlem oranı ortalaması \%63,8 iken geniş kodda ünlem oranı ortalaması \%36,2'dir. Dar koddaki ünlem oranı geniş koda göre belirgin bir biçimde fazladır. 
4.2.9. Kısaltma Kullanımı

\begin{tabular}{|c|c|c|c|c|c|c|c|}
\hline \multirow{3}{*}{$\begin{array}{l}\text { Dilsel Kodlar } \\
\text { Toplumsal Sınıflar } \\
\text { Sosyoekonomik } \\
\text { Katmanlar }\end{array}$} & \multicolumn{3}{|c|}{ Dar Kod } & \multicolumn{3}{|c|}{ Geniș Kod } & \multirow{4}{*}{$\begin{array}{l}\text { Genel } \\
\text { Toplam }\end{array}$} \\
\hline & \multicolumn{2}{|c|}{ Alt Sınıf } & \multicolumn{2}{|c|}{ Orta Sınıf } & \multicolumn{2}{|c|}{ Üst Sınıf } & \\
\hline & $\begin{array}{c}\text { En Alt } \\
\text { Katman }\end{array}$ & $\begin{array}{c}\text { Alt } \\
\text { Katman }\end{array}$ & $\begin{array}{l}\text { Orta Alt } \\
\text { Katman }\end{array}$ & $\begin{array}{l}\text { Orta } \\
\text { Katman }\end{array}$ & $\begin{array}{c}\text { Üst } \\
\text { Katman }\end{array}$ & $\begin{array}{l}\text { En Üst } \\
\text { Katman }\end{array}$ & \\
\hline $\begin{array}{l}\text { Otomobil Değer } \\
\text { Aralığı (TL) }\end{array}$ & $\begin{array}{c}0- \\
19.999\end{array}$ & $\begin{array}{l}20.000- \\
49.999\end{array}$ & $\begin{array}{l}50.000- \\
99.999\end{array}$ & $\begin{array}{l}100.000- \\
249.999\end{array}$ & $\begin{array}{l}250.000- \\
499.999\end{array}$ & $\begin{array}{l}500.000 \\
\text { ve üzeri }\end{array}$ & \\
\hline $\begin{array}{l}\text { Ölçünlü4 Kısaltma } \\
\text { Sayısı }\end{array}$ & 13 & 21 & $3^{1}$ & 45 & 23 & 23 & 156 \\
\hline $\begin{array}{l}\text { ÖIçünsüz } \\
\text { Kısaltma Sayısı }\end{array}$ & 4 & 4 & 3 & 1 & 1 & - & 13 \\
\hline $\begin{array}{l}\text { Toplam Kısaltma } \\
\text { Sayısı }\end{array}$ & 17 & 25 & 34 & 46 & 24 & 23 & 169 \\
\hline $\begin{array}{l}\text { Toplam Sözcük } \\
\text { Sayısı }\end{array}$ & 716 & 1221 & 1086 & 1574 & 1255 & 1211 & 7063 \\
\hline $\begin{array}{l}\text { Kısaltmaların } \\
\text { Toplam Sözcük } \\
\text { Sayısına Oranı }\end{array}$ & 82,37 & $\% 2,05$ & 83,13 & 82,92 & $\$ 81,91$ & 81,9 & 82,39 \\
\hline $\begin{array}{l}\text { Toplama Göre } \\
\text { Kısaltma Oranı }\end{array}$ & 816,6 & $\$ 14,36$ & $8_{21,92}$ & 820,45 & 813,37 & 813,30 & $\$ 100$ \\
\hline
\end{tabular}

Tablo 21. Kısaltma Sayıları, Dağılımları ve Oranları ${ }^{6}$

Tablo 21'de örneklemi oluşturan metinlerdeki katman, sınıf ve kodlara göre kısaltma sayıları ve bunların toplam kısaltma sayılarına göre oranları gösterilmiştir. En yüksek kısaltma kullanımı sayısı ve oranı orta katmanda; en düşük kısaltma kullanımı sayısı en alt katmanda, en düşük kısaltma kullanımı oranı ise en üst katmandadır. Katmanlar arasında kısaltma kullanımında alt katmanlardan orta katmanlara geçişte bir yükseliş, orta katmanlardan üst katmanlara geçişte ise bir düşüş olduğu dikkati çekmektedir. Kısaltma oranı orta sınıfta en yüksekken alt sınıfta nispeten düşük, üst sınıfta ise en düşüktür. Üst sınıfta kısaltmaların diğer sınıflara göre daha az kullanıldığı (\%26,67 oranında) göze çarpmaktadır. Geniş kodda kısaltma oranı ortalaması \%47,12 iken dar kodda kısaltma oranı ortalaması \%52,88'dir. Kodlar arasında oranlar birbirine çok yakın görünmekteyken kısaltma kullanımındaki fark sınıflar arasında ortaya çıkmaktadır. İmer (1990: 96) çalışmasında, çok az kısaltma kullanıldığından ve karışık biçimde yazıldıklarından dolayı kısaltma kullanımıyla ilgili anlamlı sonuçlara ulaşamamıştır.

Çalışmanın bulguları sonucunda en alt katmandan üst katmanlara geçişte ölçünsüz kısaltmaların kademeli olarak azaldığı dikkati çekmektedir. En fazla ölçünsüz kısaltma alt sınıfta (slm, fln, ppv, vd.), en az ölçünsüz kısaltma ise üst sınıftadır (ed). Kodlar arasında ise belirgin bir biçimde dar kodda ölçünsüz kısaltmaların geniş koda oranla çok daha fazla kullanıldığı tespit edilmiştir.

\footnotetext{
${ }^{6}$ Ölçünlü/ölçünsüz kısaltmaların belirlenmesinde; kısaltmanın, Türk Dil Kurumu Güncel Türkçe Sözlük (sozluk.gov.tr, Erişim Tarihi: 02.02.2021) ve Türk Dil Kurumu Kısaltmalar Dizini'nde (https://www.tdk.gov.tr/icerik/yazimkurallari/kisaltmalar-dizini/ Erişim Tarihi: 02.02.2021) yer alıp almaması, ayrıca ürün adı ya da marka/model adı olup olmadığı dikkate alınmıştır.
} 
4.2.10. Yabancı Söz Kullanımı

\begin{tabular}{|c|c|c|c|c|c|c|c|}
\hline $\begin{array}{l}\text { Dilsel } \\
\text { Kodlar }\end{array}$ & $\begin{array}{l}\text { Toplumsal } \\
\text { Sınıflar }\end{array}$ & $\begin{array}{l}\text { Sosyoekonomik } \\
\text { Katmanlar }\end{array}$ & $\begin{array}{l}\text { Otomobil } \\
\text { Değer } \\
\text { Aralığı } \\
(\mathrm{TL})\end{array}$ & $\begin{array}{l}\text { Toplam } \\
\text { Yabancı } \\
\text { Söz } \\
\text { Sayısı }\end{array}$ & $\begin{array}{l}\text { Toplam } \\
\text { Sözcük } \\
\text { Sayısı }\end{array}$ & $\begin{array}{l}\text { Yabancı } \\
\text { Sözlerin } \\
\text { Toplam } \\
\text { Sözcük } \\
\text { Sayısına } \\
\text { Oranı }\end{array}$ & $\begin{array}{l}\text { Toplama } \\
\text { Göre } \\
\text { Yabancı } \\
\text { Söz } \\
\text { Oranı }\end{array}$ \\
\hline \multirow{3}{*}{$\begin{array}{l}\text { Dar } \\
\text { Kod }\end{array}$} & \multirow{2}{*}{ Alt Sınıf } & En Alt Katman & 0.19 .999 & 3 & 716 & 80,42 & 83,94 \\
\hline & & Alt Katman & $\begin{array}{l}20.000- \\
49.999\end{array}$ & 4 & 1221 & 80,33 & $\% 3,1$ \\
\hline & Ort & Orta Alt Katman & $\begin{array}{l}50.000- \\
99.999\end{array}$ & 9 & 1086 & \&o,83 & 87,79 \\
\hline \multirow{3}{*}{$\begin{array}{l}\text { Geniș } \\
\text { Kod }\end{array}$} & & Orta Katman & $\begin{array}{l}100.000- \\
249.999\end{array}$ & 33 & 1574 & 82,1 & 819,73 \\
\hline & \multirow{2}{*}{ Üst Sınıf } & Üst Katman & $\begin{array}{l}250.000- \\
499.999\end{array}$ & 47 & 1255 & 83,75 & $8_{35,21}$ \\
\hline & & En Üst Katman & $\begin{array}{l}500.000 \\
\text { ve üzeri }\end{array}$ & 39 & 1211 & 83,22 & 830,23 \\
\hline \multicolumn{4}{|c|}{ Genel Toplam } & 135 & 7063 & 81,91 & 8100 \\
\hline
\end{tabular}

Tablo 22. Yabancı Söz Sayıları, Dağılımları ve Oranları

Tablo 22'de örneklemi oluşturan metinlerdeki katman, sınıf ve kodlara göre yabancı söz sayılarıำ ve bunların toplam yabancı söz sayılarına göre oranları gösterilmiştir. En yüksek yabancı söz kullanımı sayısı ve oranı üst katmanda; en düşük yabancı söz kullanımı sayısı en alt katmanda, en düşük yabancı söz kullanımı oranı ise alt katmandadır. Katmanlar arasında yabancı söz kullanımında alt katmanlardan üst katmanlara geçişte bir yükseliş olduğu dikkati çekmektedir. Yabancı söz oranı üst sınıfta en yüksekken orta sınıfta nispeten yüksek, alt sınıfta ise en düşüktür. Üst sınıfta yabancı sözlerin diğer sınıflara göre çok daha fazla kullanıldığı (\%65,44 oranında) göze çarpmaktadır. Geniş kodda yabancı söz oranı ortalaması \%85,17 iken dar kodda bu oran \%14,83'tür. Geniş koddaki yabancı söz kullanım oranının dar koda göre belirgin bir biçimde fazla olduğu ortadadır.

\subsection{Edimbilimsel Özellikler}

Katmanlar, sınıflar ve kodlar arasındaki dil kullanım farklılıklarının belirlenmesinde kullanılan bir başka ölçüt de edimbilimsel özelliklerdir. Bu çalışmada Bernstein'ın (1959) ortaya koyduğu edimbilimsel özelliklerden emir

\footnotetext{
7 Türkçe Sözlük'te (sozluk.gov.tr, Erişim Tarihi: 02.02.2021) yer almayan ve kaynak dildeki biçimiyle yazılan sözcükler "yabancı söz" olarak değerlendirilmiştir. Yabancı söz olarak kabul edilen örneklerden bazıları katmanlara göre şöyledir: En alt katman (orginal, aux vb.), alt katman (junyur, exper vb.), orta alt katman (ful, expertiz, double, xenon, euro vb.), orta katman (cruise, aux, clip, alcantara, expertiz, coilover, sanroof vb.), üst katman (sunroof, full, expert, stop, sound vb.), en üst katman (full, stop, expertiz, headlights,extra vb.).
} 
kullanımı ve soru kullanımına yer verilmiş, bunlara ek olarak nezaket gösteren biçimbirimler de değerlendirme kapsamına alınmış; duygusallık ve düşünme araları ise örneklemi oluşturan metinlerin özellikleri göz önünde bulundurularak kapsam dışı bırakılmıştır. Sosyoekonomik katmanlarda görülen edimbilimsel özellikler şunlardır:

4.3.1. Emir Kullanımı

\begin{tabular}{|c|c|c|c|c|c|c|c|}
\hline $\begin{array}{l}\text { Dilsel } \\
\text { Kodlar }\end{array}$ & $\begin{array}{l}\text { Toplumsal } \\
\text { Sinıflar }\end{array}$ & $\begin{array}{l}\text { Sosyoekonomik } \\
\text { Katmanlar }\end{array}$ & $\begin{array}{l}\text { Otomobil } \\
\text { Değer } \\
\text { Aralığı } \\
(\mathrm{TL})\end{array}$ & $\begin{array}{l}\text { Emir } \\
\text { Tümcesi } \\
\text { Sayısı }\end{array}$ & $\begin{array}{l}\text { Toplam } \\
\text { Çekimli } \\
\text { Eylem } \\
\text { Sayısı }\end{array}$ & $\begin{array}{l}\text { Emir } \\
\text { Tümcelerinin } \\
\text { Toplam } \\
\text { Çekimli } \\
\text { Eylem } \\
\text { Sayısına } \\
\text { Oranı }\end{array}$ & $\begin{array}{l}\text { Toplama } \\
\text { Göre } \\
\text { Emir } \\
\text { Tümcesi } \\
\text { Oranı }\end{array}$ \\
\hline \multirow{3}{*}{$\begin{array}{l}\text { Dar } \\
\text { Kod }\end{array}$} & \multirow[b]{2}{*}{ Alt Sınıf } & En Alt Katman & 0.19 .999 & 14 & 86 & $\$ 16,28$ & 832,45 \\
\hline & & Alt Katman & $\begin{array}{l}20.000- \\
49.999\end{array}$ & 10 & 114 & 98,77 & $\$ 17,48$ \\
\hline & Orta Sinıf & Orta Alt Katman & $\begin{array}{l}50.000- \\
99.999\end{array}$ & 6 & 96 & 96,25 & $\$ 12,46$ \\
\hline \multirow{3}{*}{$\begin{array}{l}\text { Geniș } \\
\text { Kod }\end{array}$} & & Orta Katman & $\begin{array}{l}100.000- \\
249.999\end{array}$ & 16 & 130 & $\% 12,30$ & $\% 24,52$ \\
\hline & \multirow{2}{*}{ Üst Sınıf } & Üst Katman & $\begin{array}{l}250.000- \\
499.999\end{array}$ & 4 & 99 & $\% 4,04$ & $\$ 8,05$ \\
\hline & & En Üst Katman & $\begin{array}{l}500.000 \\
\text { ve üzeri }\end{array}$ & 2 & 79 & 82,53 & 85,04 \\
\hline \multicolumn{4}{|c|}{ Genel Toplam } & 52 & 604 & $\$ 8,6$ & $\$ 100$ \\
\hline
\end{tabular}

Tablo 23. Emir tümcesi Sayıları, Dağılımları ve Oranları

Tablo 23'te örneklemi oluşturan metinlerdeki katman, sınıf ve kodlara göre emir tümcesi sayıları ile bunların toplam çekimli eylem ve toplam emir tümcesi sayılarına göre oranları gösterilmiştir. En yüksek emir tümcesi sayısı orta katmanda iken en düşük emir tümcesi sayısı en üst katmandadır. Oransal olarak bakıldığında en yüksek emir tümcesi kullanım oranının en alt katmanda, en düşük emir tümcesi kullanım oranının ise en üst katmanda olduğu görülmektedir. Katmanlar arasında emir tümcelerinin kullanımı bakımından en alt katman ve en üst katman arasında belirgin bir biçimde bir fark bulunduğu dikkati çekmektedir. Emir tümcesi oranı alt sınıfta en yüksekken orta sınıfta nispeten yüksek, üst sınıfta ise en düşüktür. Üst sınıfta emir tümcelerinin diğer sınıflara göre çok daha az kullanıldığı (\%13,09 oranında) göze çarpmaktadır. Geniş kodda emir tümcesi oranı ortalaması \%37,61 iken dar kodda emir tümcesi oranı ortalaması \%62,39'dur. Bu bulgular ışığında emir tümcesi kullanımında dar ve geniş kodlar arasında da belirgin bir fark olduğu tespit edilmiştir. Bernstein'a (1959: 311) göre kamu dilinin karakteristik özelliklerinden biri de "kısa emir ve soruların çok kullanılmasıdır." Çalışmadaki bulgular Bernstein'ın ifadeleriyle örtüşmektedir. 


\subsubsection{Soru Kullanımı}

\begin{tabular}{|c|c|c|c|c|c|c|c|}
\hline $\begin{array}{l}\text { Dilsel } \\
\text { Kodlar }\end{array}$ & $\begin{array}{l}\text { Toplumsal } \\
\text { Siniflar }\end{array}$ & $\begin{array}{l}\text { Sosyoekonomik } \\
\text { Katmanlar }\end{array}$ & $\begin{array}{l}\text { Otomobil } \\
\text { Değer } \\
\text { Aralığı } \\
\text { (TL) }\end{array}$ & $\begin{array}{l}\text { Soru } \\
\text { Tümcesi } \\
\text { Sayısı }\end{array}$ & $\begin{array}{l}\text { Toplam } \\
\text { Çekimli } \\
\text { Eylem } \\
\text { Sayısı }\end{array}$ & $\begin{array}{l}\text { Soru } \\
\text { Tümcelerinin } \\
\text { Toplam } \\
\text { Çekimli } \\
\text { Eylem } \\
\text { Sayısına } \\
\text { Oranı }\end{array}$ & $\begin{array}{l}\text { Toplama } \\
\text { Göre } \\
\text { Soru } \\
\text { Tümcesi } \\
\text { Oranı }\end{array}$ \\
\hline \multirow{3}{*}{$\begin{array}{l}\text { Dar } \\
\text { Kod }\end{array}$} & \multirow[b]{2}{*}{ Alt Sinıf } & En Alt Katman & $0-19.999$ & 4 & 86 & $\$ 4,65$ & $\mathscr{8}_{71,98}$ \\
\hline & & Alt Katman & $\begin{array}{l}20.000- \\
49.999\end{array}$ & $\circ$ & 114 & So & \%o \\
\hline & Orta Sınıf & Orta Alt Katman & $\begin{array}{l}50.000- \\
99.999\end{array}$ & 1 & 96 & $\% 1,04$ & $\$_{16,1}$ \\
\hline \multirow{3}{*}{$\begin{array}{l}\text { Geniș } \\
\text { Kod }\end{array}$} & & Orta Katman & $\begin{array}{l}100.000- \\
249.999\end{array}$ & 1 & 130 & \$o,77 & $\$ 11,92$ \\
\hline & \multirow{2}{*}{ Üst Sınıf } & Üst Katman & $\begin{array}{l}250.000- \\
499.999\end{array}$ & $\circ$ & 99 & so & \%o \\
\hline & & En Üst Katman & $\begin{array}{l}500.000 \\
\text { ve üzeri }\end{array}$ & $\circ$ & 79 & \%o & \%o \\
\hline \multicolumn{4}{|c|}{ Genel Toplam } & 6 & 604 & 80,99 & $\$ 100$ \\
\hline
\end{tabular}

Tablo 24. Soru Tümcesi Sayıları, Dağılımları ve Oranları

Ünlem kullanımında görüldüğü gibi soru tümcelerinde de derlemdeki metinlerin konuşma diline ait metinler olmamaları, diyalog içermemeleri, daha çok betimleme tümceleri içermeleri vb. ilan dili özelliklerinden dolayı örneklemi oluşturan metinlerde çok az sayıda soru tümcesi bulunmaktadır. Her ne kadar az sayıda veri bulunsa da Tablo 24'te örneklemi oluşturan metinlerdeki katman, sınıf ve kodlara göre soru tümceleri sayıları ile bunların toplam çekimli eylem ve toplam soru tümcesi sayılarına göre oranları gösterilmiştir. En yüksek soru tümcesi sayısı ve oranı en alt katmanda iken alt katman, üst katman ve en üst katmanda soru tümcesi bulunmamaktadır. Katmanlar arasında soru tümcesi kullanımının kademeli olarak azaldığı dikkati çekmektedir. Soru tümcesi oranı alt sınıfta çok yüksekken, orta sınıfta nispeten yüksektir; üst sınıfta ise soru tümcesi yoktur. Dar kodda soru tümcesi oranı ortalaması \%88,08 iken geniş kodda soru tümcesi oranı ortalaması \%11,92'dir. Dar koddaki soru tümcesi oranının geniş koda göre belirgin bir biçimde fazla olduğu ortadadır. Soru tümcelerinin kamu dilinde çok kullanıldığını iddia eden Bernstein'ın (1959: 311) ifadeleri ile çalışmadaki bulgular örtüşmektedir. 


\subsubsection{Nezaket Gösteren Biçimbirimler}

\subsubsection{I. Kişi İyelik Ekleri}

\begin{tabular}{|c|c|c|c|c|c|c|}
\hline $\begin{array}{l}\text { Dilsel } \\
\text { Kodlar }\end{array}$ & $\begin{array}{l}\text { Toplumsal } \\
\text { Sinıflar }\end{array}$ & $\begin{array}{l}\text { Sosyoekonomik } \\
\text { Katmanlar }\end{array}$ & $\begin{array}{l}\text { Otomobil } \\
\text { Değer } \\
\text { Aralığı } \\
\text { (TL) }\end{array}$ & $\begin{array}{l}\left\{+\left(1^{4}\right) \mathrm{m}\right\} \\
\text { kullanımı ve } \\
\text { toplam I. } \\
\text { kişi iyelik } \\
\text { eklerine } \\
\text { oranı }\end{array}$ & $\begin{array}{l}\left\{+\left.\left(I^{4}\right) \mathrm{m}\right|^{4} \mathrm{z}\right\} \\
\text { kullanımı ve } \\
\text { toplam I. kişi } \\
\text { iyelik } \\
\text { eklerine } \\
\text { oranı }\end{array}$ & $\begin{array}{l}\text { Toplam } \\
\text { I. kiși } \\
\text { iyelik eki } \\
\text { sayısı }\end{array}$ \\
\hline \multirow{3}{*}{$\begin{array}{l}\text { Dar } \\
\text { Kod }\end{array}$} & \multirow[b]{2}{*}{ Alt Sınıf } & En Alt Katman & $0-19.999$ & $11\left(\%_{100}\right)$ & $-(\% 0)$ & 11 \\
\hline & & Alt Katman & $\begin{array}{l}20.000- \\
49.999\end{array}$ & $14(877,78)$ & $4(\$ 22,22)$ & 18 \\
\hline & \multirow{2}{*}{ Orta Sınıf } & Orta Alt Katman & $\begin{array}{l}50.000- \\
99.999\end{array}$ & $8(\% 100)$ & - (\%०) & 8 \\
\hline \multirow{3}{*}{$\begin{array}{l}\text { Geniș } \\
\text { Kod }\end{array}$} & & Orta Katman & $\begin{array}{l}100.000- \\
249.999\end{array}$ & $30(\% 96,77)$ & $1(8,23)$ & 31 \\
\hline & \multirow{2}{*}{ Üst Sınıf } & Üst Katman & $\begin{array}{l}250.000- \\
499.999\end{array}$ & $17\left(8_{53}, 13\right)$ & $15(\% 46,87)$ & 32 \\
\hline & & En Üst Katman & $\begin{array}{l}500.000 \\
\text { ve üzeri }\end{array}$ & $12(\% 42,86)$ & $16(\% 57,14)$ & 28 \\
\hline \multicolumn{4}{|c|}{ Genel Toplam } & $9^{2}$ & 36 & 128 \\
\hline
\end{tabular}

\section{Tablo 25. Nezaket Gösteren Biçimbirimler (I. kişi iyelik ekleri)}

Tablo 25'te örneklemi oluşturan metinlerdeki katman, sınıf ve kodlara göre I. kişi iyelik eklerinden hareketle nezaket gösteren biçimbirimlerin sayıları ve toplama göre oranları gösterilmiştir.

Tablo 25'te I. kişi iyelik ekinin tekil ve çoğul kullanımları karşılaştırılmıştır. i̇lan metninin yazılması işleminin tek başına gerçekleştirilebilmesi göz önüne alındığında çoğul kullanım tercihinde etkili olanın, şahıstaki çokluğu ifade etmekten öte nezaket anlamı vermek olduğu düşünülmektedir. Dolaylı dil kullanımı isteğe bağlılık derecesini arttırıp karşısındakine yaptırım uygulamadığından daha kibar olma eğilimi gösterir ve bu tür kullanımlarda tümcede dolaylılık arttıkça nezaket derecesi de artar denilebilir (Leech, 1983: 108). Bu bağlamda metinlerde kullanılan I. kişi iyelik ekleri teklik-çokluk bakımından karşılaştırıldığında katmanlar arasında belirgin bir fark olduğu görülmektedir. En alt katmanda kullanılan bütün I. kişi iyelik eklerinde tekil kullanım $\left\{+l^{4} \mathrm{~m}\right\}$ (aracım, arabam, ricam vb.) tercih edilmişken çoğul kullanıma rastlanmamıştır. Bu durumun alt katman, orta alt katman ve orta katmanda da sürdüğü, çoğul kullanımına bu katmanlarda çok az yer verildiği görülmüştür. Üst katman ve en üst katmanda ise belirgin bir biçimde I. kişi iyelik ekinin çoğul kullanımına $\left\{+\left(I^{4}\right) \mathrm{ml}^{4} z\right\}$ (aracımız, arabamız, hesabımız, payımız vb.) yer verildiği görülmektedir. En üst katmanda çoğul kullanım tercihi oranı tekil kullanımın da üstüne çıkmıştır. I. kişi iyelik ekinin çoğul kullanım tercihinin üst sınıfta, alt ve orta sınıflara oranla çok daha yaygın olduğu dikkat çekicidir. Geniş kodda da dar koda oranla I. kişi iyelik ekinde çoğul kullanımın daha fazla tercih edildiği 
görülmektedir. Buradan hareketle geniş kodda tümceleri daha dolaylı yapmak ve duygudaşlık sergilemek suretiyle nezaket stratejilerine dar koda göre daha fazla yer verildiği söylenebilir.

\subsubsection{II. Kiși Emir Kipi Ekleri}

\begin{tabular}{|c|c|c|c|c|c|c|c|}
\hline $\begin{array}{l}\text { Dilsel } \\
\text { Kodlar }\end{array}$ & $\begin{array}{l}\text { Toplumsal } \\
\text { Sınıflar }\end{array}$ & $\begin{array}{l}\text { Sosyoekonomik } \\
\text { Katmanlar }\end{array}$ & $\begin{array}{l}\text { Otomobil } \\
\text { Değer } \\
\text { Aralığı } \\
\text { (TL) }\end{array}$ & $\begin{array}{l}\{-\emptyset\} \\
\text { kullanımı }\end{array}$ & $\begin{array}{l}\left\{-(y) I^{4} n\right\} \\
\text { kullanımı }\end{array}$ & $\begin{array}{l}\left\{+(y) 1^{4} n I^{4} z\right\} \\
\text { kullanımı }\end{array}$ & $\begin{array}{l}\text { Toplam } \\
\text { II. kişi } \\
\text { emir } \\
\text { kipi eki } \\
\text { sayısı }\end{array}$ \\
\hline \multirow{3}{*}{$\begin{array}{l}\text { Dar } \\
\text { Kod }\end{array}$} & \multirow{2}{*}{ Alt Sinıf } & En Alt Katman & $0-19.999$ & $\begin{array}{c}4 \\
(844,44)\end{array}$ & $\begin{array}{c}4 \\
(844,44)\end{array}$ & $1(\$ 11,11)$ & 9 \\
\hline & & Alt Katman & $\begin{array}{l}20.000- \\
49.999\end{array}$ & $-\left(x_{0}\right)$ & $1(8100)$ & $-(\% \circ)$ & 1 \\
\hline & \multirow{2}{*}{ Orta Sınıf } & Orta Alt Katman & $\begin{array}{l}50.000- \\
99.999\end{array}$ & $1(\% 50)$ & $1(\% 50)$ & $-(\% 0)$ & 2 \\
\hline \multirow{3}{*}{$\begin{array}{l}\text { Geniş } \\
\text { Kod }\end{array}$} & & Orta Katman & $\begin{array}{l}100.000- \\
249.999\end{array}$ & $1(\% 25)$ & $2\left(\%_{50}\right)$ & $1(\% 25)$ & 4 \\
\hline & \multirow{2}{*}{ Üst Sınıf } & Üst Katman & $\begin{array}{l}250.000- \\
499.999\end{array}$ & $-(\% \circ)$ & $3(\% 100)$ & $-(\% \circ)$ & 3 \\
\hline & & En Üst Katman & $\begin{array}{l}500.000 \\
\text { ve üzeri }\end{array}$ & $-\left(x_{0}\right)$ & $1(\% 50)$ & $1\left(\$_{50}\right)$ & 2 \\
\hline \multicolumn{4}{|c|}{ Genel Toplam } & 6 & 12 & 3 & 21 \\
\hline
\end{tabular}

Tablo 26. Nezaket Gösteren Biçimbirimler (II. kişi emir kipi ekleri)

Tablo 26'da örneklemi oluşturan metinlerdeki katman, sınıf ve kodlara göre II. kişi emir kipi eklerinden hareketle nezaket gösteren biçimbirimlerin sayıları ve toplama göre oranları gösterilmiştir.

$\mathrm{Bu}$ tabloda II. kişi emir kipi eklerinin tekil ve çoğul kullanımları karşılaştııılmışıı. Yukarıda değinildiği üzere dolaylııı arttıkça kibarık da artmaktadır. Türkçede dolaylılık emir kipi eklerinde ikinci tekil kişilere hitaben olsa bile ikinci çoğul kişi ekleri kullanılmak suretiyle yapılabilmektedir (Doğru, 2014: 658). "Sen al." tümcesi dolaysız ve kaba, "Siz alın." tümcesi daha dolaylı ve daha kibar, "Siz alınız." tümcesi ise bu tümceler içerisinde en dolaylı ve en kibar tümcedir. Burada dolaylılık sağlayan $\left\{-(y) I^{4} n\right\}$ ve $\left\{-(y) l^{4} n l^{4} z\right\}$ biçimbirimleri kullanılarak tümceler daha kibar duruma getirilmişlerdir. Buradan hareketle yapılan karşılaştırma sonucu daha kaba olarak değerlendirilebilecek $\{-\varnothing\}$ biçimbirimin kullanımı (al, geçme vb.) en yüksek en alt katmanda görülüyorken alt katman, üst katman ve en üst katmanda bu biçimbirim hiç kullanılmamıştır. Alt katmanlardan üst katmanlara doğru bu biçimbirimin kullanımında bir düşüş gözlenmektedir. Dar kod ve geniş kod karşılaştırıldığında da dar kodda 5, geniş kodda yalnızca 1 kez kullanıldığı görülür ve kodlar arasında belirgin bir fark olduğu söylenebilir. Dar koddan geniş koda geçişte $\{-\emptyset\}$ biçimbirimin yerine ağırlıklı olarak $\left\{-(y) l^{4} n\right\}$ ve $\left\{-(y) l^{4} n l^{4} z\right\}$ biçimbirimlerinin (ulaşın, arayın, ulaşınız, arayınız vb.) tercih edildiği gözlenmiştir. 
Bu bulgulardan hareketle geniş kodda nezaket stratejilerine dar koda göre daha fazla yer verildiği söylenebilir.

\subsection{Diğer Dil Kullanım Özellikleri}

Bu çalışmada Veith'in (2005) hazırladığı tabloda yer vermediği yazım yanlışları, noktalama yanlışları ve büyük-küçük harf kullanım tercihleri de değerlendirilmiștir. Bunlardan yazım ve noktalama yanlışları İmer (1990) tarafından da ele alınmıştır. Sosyoekonomik katmanlarda görülen diğer dil kullanım özellikleri şunlardır:

\subsubsection{Yazım Yanlıșları}

\begin{tabular}{|c|c|c|c|c|c|c|c|}
\hline Dilsel Kodlar & \multicolumn{3}{|c|}{ Dar Kod } & \multicolumn{3}{|c|}{ Geniș Kod } & \multirow{4}{*}{$\begin{array}{l}\text { Genel } \\
\text { Toplam }\end{array}$} \\
\hline Toplumsal Sınıflar & \multicolumn{2}{|c|}{ Alt Sınıf } & \multicolumn{2}{|c|}{ Orta Sınıf } & \multicolumn{2}{|c|}{ Üst Sınıf } & \\
\hline $\begin{array}{l}\text { Sosyoekonomik } \\
\text { Katmanlar }\end{array}$ & $\begin{array}{c}\text { En Alt } \\
\text { Katman }\end{array}$ & $\begin{array}{c}\text { Alt } \\
\text { Katman }\end{array}$ & $\begin{array}{l}\text { Orta Alt } \\
\text { Katman }\end{array}$ & $\begin{array}{l}\text { Orta } \\
\text { Katman }\end{array}$ & $\begin{array}{c}\text { Üst } \\
\text { Katman }\end{array}$ & $\begin{array}{l}\text { En Üst } \\
\text { Katman }\end{array}$ & \\
\hline $\begin{array}{l}\text { Otomobil Değer } \\
\text { Aralığı (TL) }\end{array}$ & $\begin{array}{c}0- \\
19.999\end{array}$ & $\begin{array}{l}20.000- \\
49.999\end{array}$ & $\begin{array}{l}50.000- \\
99.999\end{array}$ & $\begin{array}{l}100.000- \\
249.999\end{array}$ & $\begin{array}{l}250.000- \\
499.999\end{array}$ & $\begin{array}{l}500.000 \\
\text { ve üzeri }\end{array}$ & \\
\hline $\begin{array}{l}\text { Ayrı Yazılması } \\
\text { Gerekirken Bitișik } \\
\text { Yazılanlar }\end{array}$ & 4 & 9 & 3 & 16 & 7 & 16 & 55 \\
\hline $\begin{array}{l}\text { Bitişik Yazılması } \\
\text { Gerekirken Ayrı } \\
\text { Yazılanlar }\end{array}$ & 2 & 6 & 3 & 3 & 3 & 1 & 18 \\
\hline $\begin{array}{l}\{+D A\} \text { Bulunma } \\
\text { Ekinin Ayrı Yazılması }\end{array}$ & 2 & - & 5 & 1 & - & - & 8 \\
\hline $\begin{array}{l}\text { "dA" Bağlacının } \\
\text { Bitişik Yazılması }\end{array}$ & 2 & 1 & 1 & 4 & 2 & 2 & 12 \\
\hline $\begin{array}{l}\left\{\mathrm{ml}^{4}\right\} \text { Soru Ekinin } \\
\text { Bitișik Yazılması }\end{array}$ & - & - & - & 1 & - & - & 1 \\
\hline $\begin{array}{l}\{+k i\} \text { Aitlik Ekinin } \\
\text { Ayrı Yazılması }\end{array}$ & - & - & - & - & 2 & - & 2 \\
\hline $\begin{array}{l}\text { "ki" Bağlacı / } \\
\text { Pekiștirecinin Bitișik } \\
\text { Yazılması }\end{array}$ & 1 & - & - & - & - & - & 1 \\
\hline Ekin yanlıș kullanımı & 4 & 9 & 4 & 4 & 4 & 6 & 31 \\
\hline $\begin{array}{l}\text { Diğer Yazım } \\
\text { Yanlıșları }\end{array}$ & 41 & 46 & 86 & 62 & 28 & 39 & 302 \\
\hline $\begin{array}{l}\text { Toplam Yazım Yanlıșı } \\
\text { Sayısı }\end{array}$ & 56 & 71 & 102 & 91 & 46 & 64 & 430 \\
\hline Toplam Sözcük Sayısı & 716 & 1221 & 1086 & 1574 & 1255 & 1211 & 7063 \\
\hline $\begin{array}{l}\text { Yazım Yanlıșlarının } \\
\text { Toplam Sözcük } \\
\text { Sayısına Oranı }\end{array}$ & $x_{7}, 82$ & $8_{5}, 81$ & $\% 9,39$ & $8_{5,78}$ & $8_{3}, 67$ & $*_{5,28}$ & $\$ 6,09$ \\
\hline $\begin{array}{l}\text { Toplama Göre Yazım } \\
\text { Yanlıșı Oranı }\end{array}$ & $\$_{20,72}$ & 815,39 & $\$ 24,87$ & 815,31 & $\$_{9,72}$ & $\$ 13,99$ & 8100 \\
\hline
\end{tabular}

\section{Tablo 27. Yazım Yanlıșı Sayıları, Dağılımları ve Oranları}

Tablo 27'de örneklemi oluşturan metinlerdeki katman, sınıf ve kodlara göre yazım yanlışı ${ }^{8}$ sayıları ve bunların yazım yanlışları toplamına göre oranları gösterilmiştir. En yüksek yazım yanlışı sayısı ve oranı orta alt katmanda; en düşük yazım yanlışı sayısı ve oranı üst katmandadır. Yazım yanlışı oranı orta sınıfta $(\% 40,18)$ en yüksekken alt sınıfta $(\% 36,11)$ nispeten yüksek, üst sınıfta $(\% 23,71)$ ise

\footnotetext{
${ }^{8}$ Yazım yanlışlarının belirlenmesinde, Türk Dil Kurumu Güncel Türkçe Sözlük (sozluk.gov.tr, Erişim Tarihi: 02.02.2021) ve Türk Dil Kurumu Yazım Kılavuzu (tdk.gov.tr, Erişim Tarihi: 02.02.2021) dikkate alınmıștır.
} 
en düşüktür. Üst sınıfta yazım yanlışlarının diğer sınıflara göre çok daha az görüldüğü (\%23,71 oranında) göze çarpmaktadır. Dar kodda yazım yanlışı oranı ortalaması \%60,98 iken geniş kodda yazım yanlışı oranı ortalaması \%39,02'dir. Dar koddaki yazım yanlışı oranı geniş koda göre belirgin bir biçimde fazladır. İmer (1990: 135) de alt, orta ve üst olmak üzere farklı katmanlardaki ilkokul öğrencilerinin ürettikleri metinlerde yer alan yazım yanlışları ile bulgularında bu çalışmanın bulgularıyla benzer sonuçlara ulaşmıştır. İmer'in çalışmasında da üst katmandaki öğrencilerin ölçünlü Türkçeye daha uygun yazdıkları, alt katmandaki öğrencilerin ise daha çok yazım yanlışı yaptıklarını sonucu ortaya çıkmıştır.

Bulgulardan hareketle dikkati çeken bir husus da ayrı yazılması gerekirken bitişik yazılan sözcük örneklerinin (hiçbirşey, herşey, hasarkaydı, şuan vd.) ve "dA" bağlacının bitişik yazıldığı örneklerin (yada, birde, ikiside, onlarında vd.) dar koda (16/4 örnek) oranla geniş kodda (39/8 örnek) daha fazla kullanıldığının görülmesidir.

\subsubsection{Büyük Harf Kullanım Yanlışları}

\begin{tabular}{|c|c|c|c|c|c|c|c|}
\hline \multirow{3}{*}{$\begin{array}{l}\text { Dilsel Kodlar } \\
\text { Toplumsal Sınıflar } \\
\text { Sosyoekonomik } \\
\text { Katmanlar }\end{array}$} & \multicolumn{3}{|c|}{ Dar Kod } & \multicolumn{3}{|c|}{ Geniș Kod } & \multirow{4}{*}{$\begin{array}{l}\text { Genel } \\
\text { Toplam }\end{array}$} \\
\hline & \multicolumn{2}{|c|}{ Alt Sınıf } & \multicolumn{2}{|c|}{ Orta Sınıf } & \multicolumn{2}{|c|}{ Üst Sınıf } & \\
\hline & $\begin{array}{l}\text { En Alt } \\
\text { Katman }\end{array}$ & $\begin{array}{c}\text { Alt } \\
\text { Katman }\end{array}$ & $\begin{array}{l}\text { Orta Alt } \\
\text { Katman }\end{array}$ & $\begin{array}{l}\text { Orta } \\
\text { Katman }\end{array}$ & $\begin{array}{c}\text { Üst } \\
\text { Katman }\end{array}$ & $\begin{array}{l}\text { En Üst } \\
\text { Katman }\end{array}$ & \\
\hline $\begin{array}{l}\text { Otomobil Değer } \\
\text { Aralığı (TL) }\end{array}$ & $\begin{array}{c}0- \\
19.999\end{array}$ & $\begin{array}{l}20.000- \\
49.999\end{array}$ & $\begin{array}{l}50.000- \\
99.999\end{array}$ & $\begin{array}{l}100.000- \\
249.999\end{array}$ & $\begin{array}{l}250.000- \\
499.999\end{array}$ & $\begin{array}{l}500.000 \\
\text { ve üzeri }\end{array}$ & \\
\hline $\begin{array}{l}\text { Büyük Harf Olması } \\
\text { Gerekirken Küçük } \\
\text { Harfle Yazılanlar }\end{array}$ & 89 & 78 & 106 & 39 & 56 & 26 & 394 \\
\hline $\begin{array}{l}\text { Küçük Harf Olması } \\
\text { Gerekirken Büyük } \\
\text { Harfle Yazılanlar }\end{array}$ & 4 & 12 & 4 & 42 & 22 & 28 & 156 \\
\hline $\begin{array}{l}\text { Toplam Büyük } \\
\text { Harf Kullanım } \\
\text { Yanlıșı Sayısı }\end{array}$ & 93 & 90 & 110 & 81 & 78 & 54 & 550 \\
\hline $\begin{array}{l}\text { Toplam Sözcük } \\
\text { Sayısı }\end{array}$ & 716 & 1221 & 1086 & 1574 & 1255 & 1211 & 7063 \\
\hline $\begin{array}{l}\text { Büyük Harf } \\
\text { Kullanım } \\
\text { Yanlıșlarının } \\
\text { Toplam Sözcük } \\
\text { Sayısına Oranı }\end{array}$ & $\$ 12,99$ & $\$ 7,37$ & $\% 10,13$ & $\%_{5,14}$ & $\$ 6,22$ & $\$ 4,46$ & $\% 7,79$ \\
\hline $\begin{array}{l}\text { Toplama Göre } \\
\text { Büyük Harf } \\
\text { Kullanım Yanlıșı } \\
\text { Oranı }\end{array}$ & $\$ 28,05$ & $\% 15,92$ & $\% 21,87$ & $\$ 11,1$ & $\$ 13,43$ & 89,63 & $\$ 100$ \\
\hline
\end{tabular}

Tablo 28. Büyük Harf Kullanım Yanlışlarının Biçimleri, Sayıları, Dağılımları ve Oranları

Tablo 28'de örneklemi oluşturan metinlerdeki katman, sınıf ve kodlara göre büyük harf kullanım yanlışlarının sayıları ve bunların toplam büyük harf kullanım yanlışı sayılarına göre oranları gösterilmiştir. En yüksek büyük harf kullanım yanlışı sayısı orta alt katmanda, en yüksek büyük harf kullanım yanlışı oranı en alt katmanda; en düşük büyük harf kullanım yanlışı sayısı ve oranı en üst 
katmandadır. ${ }^{9}$ Katmanlar arasında büyük harf kullanım yanlışlarında alt katmanlardan üst katmanlara geçişte bir düşüş olduğu dikkati çekmektedir. Büyük harf kullanım yanlışı oranı alt sınıfta en yüksekken orta sınıfta nispeten yüksek, üst sınıfta ise en düşüktür. Alt sınıfta büyük harf kullanım yanlışlarının diğer sınıflara göre çok daha fazla kullanıldığı (\%43,97 oranında) göze çarpmaktadır. Dar kodda büyük harf kullanım yanlışı oranı ortalaması \%65,84 iken geniş kodda büyük harf kullanım yanlışı oranı ortalaması \%34,16'dır. Dar koddaki büyük harf kullanım yanlışı oranı geniş koda göre belirgin bir biçimde fazladır.

İmer (1990: 85-86) çalışmasında alt katman çocukları tarafından büyük harflerin nerede kullanılacağının çoğunlukla bilinmediğini ve bu nedenle büyük harflerin gelişigüzel kullanıldığını; üst katman çocuklarında büyük harf kullanımının alt ve orta katman çocuklarından daha çok yerleşmiş olduğunu tespit etmiştir. Büyük harf kullanım yanlışları bakımından bu çalışmanın bulguları ile İmer'in çalışmasındaki bulguların örtüştüğü söylenebilir.

\subsubsection{Noktalama Yanlıșları}

\begin{tabular}{|c|c|c|c|c|c|c|c|}
\hline \multirow{3}{*}{$\begin{array}{l}\text { Dilsel Kodlar } \\
\text { Toplumsal Sınıflar } \\
\text { Sosyoekonomik } \\
\text { Katmanlar }\end{array}$} & \multicolumn{3}{|c|}{ Dar Kod } & \multicolumn{3}{|c|}{ Genişs Kod } & \multirow{4}{*}{$\begin{array}{l}\text { Genel } \\
\text { Toplam }\end{array}$} \\
\hline & \multicolumn{2}{|c|}{ Alt Sınıf } & \multicolumn{2}{|c|}{ Orta Sınıf } & \multicolumn{2}{|c|}{ Üst Sınıf } & \\
\hline & $\begin{array}{c}\text { En Alt } \\
\text { Katman }\end{array}$ & $\begin{array}{c}\text { Alt } \\
\text { Katman }\end{array}$ & $\begin{array}{l}\text { Orta Alt } \\
\text { Katman }\end{array}$ & $\begin{array}{l}\text { Orta } \\
\text { Katman }\end{array}$ & $\begin{array}{c}\text { Üst } \\
\text { Katman }\end{array}$ & $\begin{array}{l}\text { En Üst } \\
\text { Katman }\end{array}$ & \\
\hline $\begin{array}{l}\text { Otornobil Değer } \\
\text { Aralığı (TL) }\end{array}$ & $\begin{array}{c}0- \\
19.999\end{array}$ & $\begin{array}{l}20.000- \\
49.999\end{array}$ & $\begin{array}{l}50.000- \\
99.999\end{array}$ & $\begin{array}{l}100.000- \\
249.999\end{array}$ & $\begin{array}{l}250.000- \\
499.999\end{array}$ & $\begin{array}{l}500.000 \\
\text { ve üzeri }\end{array}$ & \\
\hline Virgül Eksikliği & 42 & 32 & 87 & 68 & 65 & 56 & 350 \\
\hline Nokta Eksikliği & 102 & 143 & 173 & 110 & 84 & 110 & 722 \\
\hline $\begin{array}{l}\text { Gereksiz Virgül } \\
\text { Kullanımı }\end{array}$ & 5 & 7 & 6 & 9 & 2 & - & 29 \\
\hline $\begin{array}{l}\text { Noktalamadan } \\
\text { Sonra Boşluk } \\
\text { Bırakılmayan } \\
\text { Örnekler }\end{array}$ & 6 & 15 & 10 & 28 & 18 & 30 & 107 \\
\hline $\begin{array}{l}\text { Noktalamadan } \\
\text { Önce Boşluk } \\
\text { Bırakılan Örnekler }\end{array}$ & 2 & 10 & 8 & 10 & 1 & 5 & 36 \\
\hline $\begin{array}{l}\text { Ayraçlardan Önce } \\
\text { ya da Sonra } \\
\text { Boșluk Bırakılan } \\
\text { Örnekler }\end{array}$ & - & 2 & - & 8 & - & - & 10 \\
\hline $\begin{array}{l}\text { Toplam } \\
\text { Noktalama Yanlıșı }\end{array}$ & 157 & 209 & 284 & 233 & 170 & 201 & 1254 \\
\hline $\begin{array}{l}\text { Toplam Sözcük } \\
\text { Sayısı }\end{array}$ & 716 & 1221 & 1086 & 1574 & 1255 & 1211 & 7063 \\
\hline $\begin{array}{l}\text { Noktalama } \\
\text { Yanlıșlarının } \\
\text { Toplam Sözcük } \\
\text { Sayısına Oranı }\end{array}$ & 821,93 & $\$_{17,12}$ & 826,15 & $x_{14}, 80$ & $\$ 13,55$ & 816,6 & $\$_{17,75}$ \\
\hline $\begin{array}{l}\text { Toplama Göre } \\
\text { Noktalama Yanlıșı } \\
\text { Oranı }\end{array}$ & 819,91 & $\$ 15,54$ & $\$ 23,74$ & $\$ 13,44$ & 812,3 & $x_{15,07}$ & $\$ 100$ \\
\hline
\end{tabular}

\section{Tablo 29. Noktalama Kullanım Yanlıșı Sayıları, Dağılımları ve Oranları}

Tablo 29'da örneklemi oluşturan metinlerdeki katman, sınıf ve kodlara göre noktalama yanlışı sayıları ve bunların toplam noktalama yanlışı sayılarına

\footnotetext{
9 Tamamı büyük harfle yazılan açıklamalar sayıya dâhil edilmemiştir.
} 
göre oranları gösterilmiştir. En yüksek noktalama yanlışı sayısı ve oranı orta alt katmanda; en düşük noktalama yanlışı sayısı en alt katmanda, en düşük noktalama yanlışı oranı üst katmandadır. Hem yazım yanlışlarının hem de noktalama yanlışlarının en yüksek oranda orta alt katmanda görülmesi ayrıca dikkat çekicidir. Noktalama yanlışı oranı orta sınıfta $(\% 37,18)$ en yüksekken alt sınıfta $(\% 35,45)$ nispeten yüksek, üst sınıfta $(\% 27,37)$ ise en düşüktür. Üst sınıfta noktalama yanlışlarına diğer sınıflara göre çok daha az rastlandığı (\%27,37 oranında) göze çarpmaktadır. Dar kodda noktalama yanlışı oranı ortalaması \%59,19 iken geniş kodda bu oran \%40,81'dir. Dar koddaki noktalama yanlışı oranı geniş koda göre belirgin bir biçimde fazladır.

İmer (1990: 89-92) çalışmasında, noktalama yanlışlarına ilişkin olarak yalnızca noktanın kullanım yanlışlarına odaklanmış; alt katman çocuklarında bu yanlışlara daha fazla rastlandığı, üst katman çocuklarında ölçünlü dile daha yakın bir kullanım görüldüğü sonucuna ulaşmıştır. Tablo 26'da görüleceği üzere bu çalışmada birden fazla noktalama işaretinin (nokta, virgül, ayraç vd.) yanlış kullanımı değerlendirmeye alınmıştır. Noktalama yanlışları bakımından bu çalışmanın bulguları ile İmer'in çalışmasındaki bulguların örtüştüğü söylenebilir.

Bulgulardan hareketle dikkati çeken bir husus da virgül eksikliği ve noktalamadan sonra boşluk bırakılmayan örneklerin dar koda (161/31 örnek) oranla geniş kodda (189/76 örnek) daha fazla kullanıldığının görülmesidir.

\subsubsection{Büyük-Küçük Harf Kullanım Tercihleri}

\begin{tabular}{|c|c|c|c|c|c|c|c|}
\hline \multirow{3}{*}{$\begin{array}{l}\text { Dilsel Kodlar } \\
\text { Toplumsal Sınıflar } \\
\text { Sosyoekonomik } \\
\text { Katmanlar }\end{array}$} & \multicolumn{3}{|c|}{ Dar Kod } & \multicolumn{3}{|c|}{ Geniș Kod } & \multirow{4}{*}{$\begin{array}{l}\text { Genel } \\
\text { Toplam }\end{array}$} \\
\hline & \multicolumn{2}{|c|}{ Alt Sınıf } & \multicolumn{2}{|c|}{ Orta Sınıf } & \multicolumn{2}{|c|}{ Üst Sınıf } & \\
\hline & $\begin{array}{c}\text { En Alt } \\
\text { Katman }\end{array}$ & $\begin{array}{c}\text { Alt } \\
\text { Katman }\end{array}$ & $\begin{array}{l}\text { Orta Alt } \\
\text { Katman }\end{array}$ & $\begin{array}{l}\text { Orta } \\
\text { Katman }\end{array}$ & $\begin{array}{c}\text { Üst } \\
\text { Katman }\end{array}$ & $\begin{array}{c}\text { En Üst } \\
\text { Katman }\end{array}$ & \\
\hline $\begin{array}{l}\text { Otomobil Değer } \\
\text { Aralığı (TL) }\end{array}$ & $\begin{array}{c}0- \\
19.999\end{array}$ & $\begin{array}{l}20.000- \\
49.999\end{array}$ & $\begin{array}{l}50.000- \\
99.999\end{array}$ & $\begin{array}{l}100.000- \\
249.999\end{array}$ & $\begin{array}{l}250.000- \\
499.999\end{array}$ & $\begin{array}{l}500.000 \\
\text { ve üzeri }\end{array}$ & \\
\hline $\begin{array}{l}\text { Bir Bölümünün } \\
\text { Tamamı Büyük } \\
\text { Harfle Yazılan ilan } \\
\text { Sayısı }^{8}\end{array}$ & - & 的 & 的 & - & ホフフ・ファ & 5 & 13 \\
\hline $\begin{array}{l}\text { Tamamı Büyük } \\
\text { Harfle Yazılan ilan } \\
\text { Sayısı }\end{array}$ & - & 4 & 3 & 10 & 5 & 13 & 35 \\
\hline Toplam ilan Sayısı & 25 & 25 & 25 & 25 & 25 & 25 & 150 \\
\hline $\begin{array}{l}\text { Tamamı Büyük } \\
\text { Harfle Yazılan } \\
\text { ilanların Toplam } \\
\text { İlan Sayısına Oranı }\end{array}$ & \%o & $\$ 16$ & $\$ 12$ & 840 & $\% 20$ & 852 & $\$ 23,33$ \\
\hline $\begin{array}{l}\text { Toplama Göre } \\
\text { Tamamı Büyük } \\
\text { Harfle Yazılan ilan } \\
\text { Oranı }\end{array}$ & So & $\$ 11,43$ & 88,57 & $\mathrm{x}_{28,57}$ & $x_{14,29}$ & 837,14 & $\$ 100$ \\
\hline
\end{tabular}

Tablo 30. Tamamı ve Bir Bölümünün Tamamı Büyük Harfle Yazılan İlan Sayıları, Dağılımları ve Oranları ${ }^{10}$

\footnotetext{
${ }^{10}$ Bir Bölümün Tamamı Büyük Harfle Yazılan İlan ifadesi ile, ilan metninin geneli büyük harf kullanımı açısından
} normal tümce düzeninde iken bir ya da birkaç tümceyi oluşturan sözcüklerin tamamının büyük harfle yazılması 
Tablo 30'da örneklemi oluşturan metinlerdeki katman, sınıf ve kodlara göre tamamı büyük harf kullanılarak yazılan ilan sayıları ve bunların tamamı büyük harf kullanılarak yazılan ilan sayılarının toplamına göre oranları gösterilmiştir. Ayrıca bir bölümünün tamamı büyük harfle yazılan ilan sayılarında da tabloda yer verilmiştir. En yüksek tamamı büyük harf kullanılarak yazılan ilan sayısı ve oranı en üst katmanda; en düşük tamamı büyük harf kullanılarak yazılan ilan sayısı ve oranı ise bu şekilde yazılan ilanın hiç olmadığı en alt katmandadır. Katmanlar arasında tamamı büyük harf kullanılarak yazılan ilan sayılarında alt katmanlardan üst katmanlara geçişte bir yükseliş olduğu dikkati çekmektedir. Tamamı büyük harf kullanılarak yazılan ilan oranı üst sınıfta en yüksekken orta sınıfta nispeten yüksek, alt sınıfta ise en düşüktür. Üst sınıfta tamamı büyük harf kullanılarak yazılan ilanların diğer sınıflara göre çok daha fazla kullanıldığı $\% 51,43$ oranında) göze çarpmaktadır. Dar kodda bu şekilde yazılan ilan oranı ortalaması \%20 iken geniş kodda bu oran \%80'dir. Bu bulgular ışığında geniş kodda yazılan ilanlarda tümcelerin tamamını büyük harfle yazma eğilimi dar koda göre belirgin bir biçimde fazladır denilebilir.

\section{Değerlendirme ve Sonuç}

Çalışmada tüketiciden tüketiciye elektronik ticaret olanağı sağlayan sahibinden.com internet sitesindeki otomobil ilan açıklamalarında; değer aralıklarından hareketle sosyoekonomik katmanlar, toplumsal sınıflar ve dilsel kodlara göre belirlenen farklı dil kullanım özellikleri hakkında birtakım sonuçlara ulaşıımıştır. Öne çıkan sonuçlar şöyle sıralanabilir:

- Dilsel kodlar arasındaki farklılıkların sosyoekonomik katmanlar ve toplumsal sınıflar arasındaki farklılıklardan daha belirgin olduğu görülmüştür.

- Metinlerdeki sözcük ve tümce sayılarında kodlar arasında farklılıklar olduğu tespit edilmiştir. Dar kodun hem sözcük hem de tümce sayısı yönünden geniş koda göre daha sınırlı olduğu saptanmıştır.

- Dar koddaki tümcelerin geniş koda oranla belirgin biçimde daha kısa olduğu görülmüştür.

- Dar kodda basit tümce kullanım oranının geniş koda oranla daha fazla olduğu tespit edilmiştir.

- Dar kodda basmakalıp ifadelere geniş koda oranla daha sık yer verildiği görülmüştür.

- Dar kodda etken eylem biçimleri daha fazla tercih edilirken geniş kodda edilgen eylem biçimlerinin fazlalığı dikkati çekmektedir.

- Dar kodda geniş koda göre daha fazla devrik tümce olduğu görülmüştür.

kastedilmiştir. Örnek olarak “...demeyin çok cüzi miktarda pazarlık payı vardır ben olurunu yazdım. ARAÇ GÖRÜLÜR ONDAN SONRA PAZARLIK EDILIR" ilan metni son tümceye kadar büyük-küçük harf kullanımı bakımından normal tümce düzeninde iken bu son tümcede metnin tamamında büyük harf kullanımı tercih edilmiştir. 
- Üst sınıftaki bağlaç kullanım oranının diğer sınıflara oranla çok daha yüksek olduğu tespit edilmiştir.

- Belirsizlik adıllarının geniş kodda dar koda oranla çok daha fazla kullanılmış olması dikkat çekmektedir.

- Ölçünsüz kısaltma kullanımı dikkate alındığında bu türden kısaltmalara dar kodda geniş koda oranla daha fazla yer verildiği belirlenmiştir.

- Çalışmada kodlar arasında en belirgin farkın görüldüğü özelliklerden biri yabancı söz kullanımı olmuştur. Geniş kodda yabancı sözlere \%85,17, dar kodda $\% 14,83$ oranında yer verilmiştir.

- Soru kullanımı dar kodda geniş koda oranla çok daha fazladır.

- Leech'in (1983) dolaylı dil kullanımının kibarlığı arttırdığı ifadesinden hareketle, I. kişi iyelik ekinin çoğul kullanımının geniş kodda dar koda oranla daha fazla tercih edilmesinin ve II. kişi emir kipinde geniş kodda $-\varnothing$ biçimbirimin yerine ağıllıklı olarak $\left\{-\left.(y)\right|^{4} n\right\}$ ve $\left\{-\left.(y)\right|^{4} n l^{4} z\right\}$ biçimbirimlerinin dar koda göre daha fazla tercih edilmesinin, geniş koddaki nezaket derecesini arttırdığı söylenebilir. Kısacası geniş koddaki nezaket ifadeleri dar koda göre daha fazladır.

- Dar kodda geniş koda oranla çok daha fazla yazım yanlışı bulunduğu saptanmıştır.

- Noktalama yanlışları da dar kodda geniş koda oranla çok daha fazladır.

- Geniş kodda, ilanların tamamını büyük harfle yazma tercihinin dar koda oranla belirgin biçimde fazla olduğu ortaya çıkmıştır.

- Dar ve geniş kod arasında görülen en belirgin farklııkların büyük - küçük harf kullanım tercihlerinde ve yabancı söz kullanımında ortaya çıktığı söylenebilir.

Özetle geniş koddaki dil kullanııılarının dar koddaki dil kullanıılarına oranla ölçünlü Türkçeye daha yakın metin ürettiklerini söylemek mümkündür. Bunun nedeni olarak başta geniş koddaki dil kullanıcılarının eğitim düzeyinin dar koddakilere oranla daha yüksek olduğu çıkarımı yapılabilir. Ayrıca muhakkak gelir durumu, meslek, muhit (çevre) gibi toplumsal sınıf değişkenleri de bu durumda rolü olan etmenler arasında sayılabilir

Çalışmadaki sosyoekonomik katmanlar, toplumsal sınıflar ve dilsel kodlar için yapılan genellemelerde istisnai durumların da görülebileceği göz ardı edilmemelidir. Çalışmanın bulgular bölümünde dil kullanımına ilişkin betimleyici istatistiksel tablolar ışı̆̆ında birtakım benzerlikler ve farklılıklar ortaya çıkmıştır. Tablo 31'de dilsel kodlara göre tespit edilen dil kullanım özellikleri toplu olarak gösterilmiştir. 


\begin{tabular}{|c|c|c|c|}
\hline \multicolumn{2}{|r|}{ ÖLÇÜT } & GENIŞ KOD & DAR KOD \\
\hline \multirow{9}{*}{ 1. söz dizimi } & Tümce Uzunluğu & $\begin{array}{l}\text { Nispeten uzun } \\
\text { tümceler }\end{array}$ & $\begin{array}{l}\text { Nispeten kısa } \\
\text { tümceler }\end{array}$ \\
\hline & Tümce Yapısı & Karmașık & Basit \\
\hline & Tümce Biçimi & Değișken & Basmakalıp \\
\hline & Edilgen çatılı eylem kullanımı & Sık & Seyrek \\
\hline & $\begin{array}{l}\text { Yüklemin Türüne Göre } \\
\text { Tümceler }\end{array}$ & $\begin{array}{c}\text { Eylem tümcesi } \\
\text { daha az, ad } \\
\text { tümcesi daha çok }\end{array}$ & $\begin{array}{c}\text { Eylem tümcesi daha } \\
\text { çok, ad tümcesi } \\
\text { daha az }\end{array}$ \\
\hline & Yüklemin Yerine Göre Tümce & Kurallı (daha çok) & Devrik (daha çok) \\
\hline & Ortaç Kullanımı & -9 & - \\
\hline & Ulaç Kullanımı & Sık & Seyrek \\
\hline & Adeylem Kullanımı & Sık & Seyrek \\
\hline \multirow{9}{*}{ 2. SÖZ VARLIĞI } & Çeșitlilik & - & - \\
\hline & Önad Kullanımı & - & - \\
\hline & Belirteç Kullanımı & - & - \\
\hline & îlgeç Kullanımı & Çeșitlilik çok & Çeşitlilik az \\
\hline & Bağlaç Kullanımı & Oldukça sık & Oldukça nadir \\
\hline & Adıl Kullanımı & $\begin{array}{l}\text { Belirsizlik adılları } \\
\text { sık }\end{array}$ & $\begin{array}{l}\text { Belirsizlik adılları } \\
\text { seyrek }\end{array}$ \\
\hline & Ünlem Kullanımı & Seyrek & Sık \\
\hline & Kısaltma Kullanımı & Ölçünlü & Ölçūnsüz \\
\hline & Yabancı Söz Kullanımı & Oldukça sık & Oldukça nadir \\
\hline \multirow{3}{*}{$\begin{array}{l}\text { 3. EDIMBILIMSEL } \\
\text { ÖZELLIKLER }\end{array}$} & Emir Kullanımı & Oldukça nadir & Oldukça sık \\
\hline & Soru Kullanımı & Oldukça nadir & Oldukça sık \\
\hline & $\begin{array}{l}\text { Nezaket Gösteren } \\
\text { Biçimbirimler }\end{array}$ & Oldukça sık & Oldukça nadir \\
\hline \multirow{4}{*}{$\begin{array}{l}\text { 4. DIĞER DİL } \\
\text { KULLANIM } \\
\text { ÖZELLIKLERİ }\end{array}$} & Yazım Yanlıșları & Oldukça sık & Oldukça nadir \\
\hline & Büyūk Harf Kullanım Yanlıșları & Oldukça sık & Oldukça nadir \\
\hline & Noktalama Yanlışları & Oldukça sık & Oldukça nadir \\
\hline & $\begin{array}{l}\text { Metnin Tamamını Büyük } \\
\text { Harflerle Olușturma }\end{array}$ & Oldukça sık & Oldukça nadir \\
\hline
\end{tabular}

Tablo 31. Genel Değerlendirme: Kodlara Göre Dil Kullanımı ${ }^{11}$

\section{Kaynakça}

Ash, S. (2013). Social Class. The handbook of Language Variation and Change, (Editörler: J.K. Chambers \& Natalie Schilling). s.350-367.

Bernstein, B. (1958). Some Sociological Determinants of Perception, The British $\begin{array}{llllll}\text { Journal of Sociology, Cilt } & 9 & \text { Sayı } & 2 & \text { s.159-774. }\end{array}$ https://www.jstor.org/stable/587912?seq=1

Bernstein, B. (1959). A Public Language: Some Sociological Implications of a Linguistic Form, The British Journal of Sociology, Cilt 10, No 4. 5.311-326. https://www.jstor.org/stable/587797?seq=1

Bernstein, B. (1962). Social Class, Linguistic Codes and Grammatical Elements. Language and Speech, 5(4), s.221-240.

Biber, D. (1990). Methodological Issues Regarding Corpus-based Analysis of Linguistic Variation. Literary and Linguistic Computing 5(4): ss.257-269.

Bussmann, H. (2006). Routledge Dictionary of Language and Linguistics. Routledge. 
Büyükkantarcıoğlu, N. (1992). İstanbul'daki Üç illkokulda Farklı Sosyal Katmanlardan Gelen Üçüncü ve Beşinci Sınıf Öğrencilerinde Ölçüt-dil Sözcük Dağarcığı Farklılıkları. Gazi Eğitim Fakültesi Dergisi, 8(3), s.227-237.

Çolak, G. (2003). Ergenlik Dönemindeki Çocukların Sosyoekonomik Şartlar Çerçevesinde Dili Kullanma Biçimleri (Yüksek Lisans Tezi). Ankara: Gazi Üniversitesi Sosyal Bilimler Enstitüsü.

Çolak, G. (2008), Türkçedeki Temel Kelimelerin Cinsiyetlere Göre Çağrışım Setleri (Doktora Tezi). Ankara: Gazi Üniversitesi Sosyal Bilimler Enstitüsü.

Dağabakan, F. Ö. (2012). Toplumdilbilimsel Bir Kavram Olarak Kadın-Erkek Dil Ayrımına Türkçe ve Almanca Açısından Bir Yaklaşım. Atatürk Üniversitesi Türkiyat Araştırmaları Enstitüsü Dergisi, (47), s.87-106.

Dağabakan, F. Ö. (2019). Toplumdilbilim. Konya: Çizgi Kitabevi.

Dittmann, J. \& Goebel, J. (2010). Your House, your Car, your Education: The Socioeconomic Situation of the Neighborhood and its Impact on Life Satisfaction in Germany. Social Indicators Research, 96(3), s.497-513.

Doğru, F. (2014). Türkçe Buyrum Tümcelerinde Kibarlık / Kabalık, VI. Uluslararası Dünya Dili Türkçe Sempozyumu Bildirileri (Editörler: Hatice Şahin ve İbrahim Karahanci), C.1, s.651-669, Bursa: Star Ajans.

Eker, S. (2007). Toplumdilbilgisel Bir Gösterge Olarak /e/. Süer Eker \& Ayşenur Külahlığlu i̇slam (Ed.), Edebiyat ve Dil Yazıları içinde (s.231-247). Ankara: Grafiker Yayınları.

Giddens, A. (2012). Sosyoloji. (Yayıma hazırlayan Cemal Güzel) İstanbul: Kırmızı Yayınları.

Guofang, Z. \& Jianli, Xu (2008). Empirical Analysis upon Factors Affecting Private Car Purchase Decision-Making. Auto Industry Research, 15.

İmer, K. (1990). Dil ve toplum. Ankara: Gündoğan Yayınları.

İmer, K., Kocaman, A. \& Özsoy, A. S. (2013). Dilbilim Sözlüğü. İstanbul: Boğaziçi Üniversitesi Yayınevi.

Kalaycıoğlu, S. (2002). Toplumsal Tabakalaşma, ihsan Sezal (Ed.), Sosyolojiye Giriş (s.295-316). Ankara: Martı Yayınevi.

Labov, W. (1966) 2006. The social stratification of English in New York City (2. Baskı). Cambridge, UK: Cambridge University Press.

Labov, W. (2001) Principles of Linguistic Change. (Volume II: Social Factors). Oxford: Basil Blackwell.

Leech, G. (1983). Principles of Pragmatics. New York: Longman.

Paulston, C. B., \& Tucker, G. R. (Ed.). (2003). Sociolinguistics: The Essential Readings. Oxford: Blackwell.

Swann, J., Deumert, A., Lillis, T., \& Mesthrie, R. (2004). A Dictionary of Sociolinguistics. Edinburgh: Edinburgh University Press Ltd.

Sweet, E. (2010). "If your shoes are raggedy you get talked about": Symbolic and material dimensions of adolescent social status and health. Social Science \& Medicine, 70(12), s.2029-2035.

Şahin, C. \& Karakaş, A. (2017). Dünya'da ve Türkiye'de e-ticaret Sektörü, ICMEB'17 International Congress on Management Economics and Business 
(Uluslararası Yönetim İktisat ve İşletme Kongresi) Proceedings / Bildiriler Kitabı (Editörler: Hamza Çeştepe ve Ertuğrul Yıldırım), 27-33, Zonguldak.

Şahin, E. \& Kaya, F. (2019). Tüketiciden Tüketiciye E-Ticaret Olanağı Sağlayan Web Sitelerinin Deneyimsel Pazarlama Faaliyetlerinin Tüketicilerin Plansız Satın Alma Davranışlarına ve Tatminlerine Etkisi: Konya İli Örneği, Selçuk Üniversitesi Sosyal Bilimler Enstitüsü Dergisi, (41), 255-280.

Şengül, M. (2009). Sosyal Farklılıklardan Kaynaklanan Dil Kullanımı ve Türkçe Eğitimine Yönelik Bir Değerlendirme. Turkish Studies, International Periodical For The Language and Literature and History of Turkish or Turkic, 4(8), $2166-2180$.

Trudgill, P. (1974). The Social Differentiation of English in Norwich (Vol. 13). Cambridge Studies in Lingustics. Cambridge: Cambridge University Press.

Veith, H. W. (2005). Soziolinguistik: Ein Arbeitsbuch mit 104 Abbildungen, Kontrollfragen und Antworten, (Revize edilmiş 2. baskı), Tübingen: Gunter Narr Verlag.

Wang, J. \& Quan, J. (2019). Analysis of Family Car Ownership Among Different Groups in 2012. Development of a Society on Wheels . Singapore: Springer. 165-180.

Yılmaz, T. (1974). Eğitimde Eşitsizliğin Kaynaklarından Biri Olarak Dil Yapısının Okul Başarısındaki Rolü. Ankara: Ankara Basım ve Ciltevi.

Elektronik kaynaklar:

Güncel Türkçe Sözlük. 2 Şubat 2021 tarihinde https://sozluk.gov.tr/ adresinden erişildi.

Lexically. $\quad$ (2021). $\quad 12 \quad$ Şubat $\quad 2021 \quad$ tarihinde https://lexically.net/downloads/version6/HTML/ type token_ratio_proc.htm adresinden erişildi.

Sahibinden, 31 Ocak 2021 tarihinde https://www.sahibinden.com/ adresinden erişildi.

Türk Dil Kurumu, 2 Şubat 2021 tarihinde https://www.tdk.gov.tr/ adresinden erișildi.

Worldometers. (2021). $\quad 3 \quad$ Şubat 2021 tarihinde https://www.worldometers.info/world-population/ adresinden erişildi. 